\title{
The Use of Artificial Neural Networks for Determining Values of Selected Strength Parameters of Miscanthus $\times$ Giganteus
}

\author{
Sławomir Francik ${ }^{1, * ®}$, Bogusława Łapczyńska-Kordon ${ }^{1}$, Norbert Pedryc ${ }^{1} \oplus$, Wojciech Szewczyk ${ }^{2}$, \\ Renata Francik ${ }^{3,4}$ and Zbigniew Ślipek ${ }^{1,5}$ (D)
}

1 Department of Mechanical Engineering and Agrophysics, Faculty of Production Engineering and Energetics, University of Agriculture in Krakow, Balicka 120, 30-149 Krakow, Poland;

boguslawa.lapczynska-kordon@urk.edu.pl (B.Ł.-K.); norbert.pedryc@urk.edu.pl (N.P.); zbigniew.slipek@urk.edu.pl (Z.Ś.)

2 Department of Agroecology and Plant Production, University of Agriculture in Krakow, Al. Mickiewicza 21, 31-120 Krakow, Poland; wojciech.szewczyk@urk.edu.pl

3 Department of Bioorganic Chemistry, Chair of Organic Chemistry, Jagiellonian University Medical College, 30-688 Krakow, Poland; renata.francik@uj.edu.pl

4 Institute of Health, State Higher Vocational School, Staszica 1, 33-300 Nowy Sacz, Poland

5 Technical Institute, State Higher Vocational School, Staszica 1, 33-300 Nowy Sacz, Poland

* Correspondence: slawomir.francik@urk.edu.pl; Tel.: +48-12-662-46-41

check for

updates

Citation: Francik, S.;

Łapczyńska-Kordon, B.; Pedryc, N.; Szewczyk, W.; Francik, R.; Ślipek, Z The Use of Artificial Neural Networks for Determining Values of Selected Strength Parameters of

Miscanthus $\times$ Giganteus.

Sustainability 2022, 14, 3062. https:/ / doi.org/10.3390/su14053062

Academic Editors: Gwanggil Jeon and Hossein Bonakdari

Received: 31 December 2021

Accepted: 3 March 2022

Published: 6 March 2022

Publisher's Note: MDPI stays neutral with regard to jurisdictional claims in published maps and institutional affiliations.

Copyright: (C) 2022 by the authors. Licensee MDPI, Basel, Switzerland. This article is an open access article distributed under the terms and conditions of the Creative Commons Attribution (CC BY) license (https:// creativecommons.org/licenses/by/ $4.0 /)$.

\begin{abstract}
The aim of this paper is to develop neural models enabling the determination of biomechanical parameters for giant miscanthus stems. The static three-point bending test is used to determine the bending strength parameters of the miscanthus stem. In this study, we assume the modulus of elasticity bending and maximum stress in bending as the dependent variables. As independent variables (inputs of the neural network) we assume water content, internode number, maximum bending force value and dimensions characterizing the cross-section of miscanthus stem: maximum and minimum stem diameter and stem wall thickness. The four developed neural models, enabling the determination of the value of the modulus of elasticity in bending and the maximum stress in bending, demonstrate sufficient and even very high accuracy. The neural networks have an average relative error of $2.18 \%, 2.21 \%, 3.24 \%$ and $0.18 \%$ for all data subsets, respectively. The results of the sensitivity analysis confirmed that all input variables are important for the accuracy of the developed neural models-correct semantic models.
\end{abstract}

Keywords: biomechanical parameters; miscanthus stem; modulus of elasticity; maximum stress; bending test; multilayer perceptron

\section{Introduction}

At the UN Sustainable Development Summit in 2015, the 2030 Agenda for Sustainable Development with the 17 Sustainable Development Goals was adopted. Goal number 7- "Clean and affordable energy" is related to activities for the development of sustainable and modern energy - renewable energy sources.

One of the very important applications of plant (lignocellulosic) biomass is its use as a renewable energy source. The percentage share of cellulose, hemicellulose and lignin in a given type of biomass may vary, which significantly affects its energy parameters and the possibility of using it for the production of biofuels [1]. Research is carried out on woody [2-4] and herbaceous biomass [5], but also pomaces, fruit stones, kernel shells and other residuals [6-9], and recently on so-called water biomass (algae) $[10,11]$.

The giant miscanthus (miscanthus $\times$ giganteus) is one of the most productive plant species, which, thanks to the fast and abundant biomass production, can provide the required amounts of the raw material. It is characterized by a high biomass production potential, which means that it is used to establish industrial biomass plantations throughout 
Europe and the USA [12-15]. Giant miscanthus can be successfully used in the production of compact solid biofuels [16-19], biogas and bioethanol [20-22]. Miscanthus' biomass is used in the production of technical papers, cardboard, packaging plywood or fibers for lining packaging. It can also be a substitute for plastics in the production of packaging [23]. Studies are carried out on miscanthus fibers to develop renewable construction materialslightweight concrete [24].

The necessity to determine the mechanical properties of materials of plant origin is crucial in the process of designing specific machines for their processing, as well as in the selection of optimal conditions for their operation. It is difficult because the mechanical properties of these types of materials change depending on the environmental conditions (e.g., water content). The results of research on the biomechanical properties of industrial plant stems are used in designing better and more efficient biomass processing equipment (e.g., harvesting and grinding machines) [25-32]. Biomechanical properties can also be used as a selection criterion in a plant breeding program-assessing and adjusting stem mechanical traits may improve stem lodging resistance [33].

Typical laboratory tests aimed at determining the biomechanical properties of plant stems include: bending tests [27-29,33-36], compression tests along or across the stem $[36,37]$, tensile tests $[27,32,36]$, shearing tests $[27,29,36]$ and cutting tests [26-28].

In the case of bending, the typical strength parameters determined in the studies of stems of various plants are the modulus of elasticity for bending $[27,29,34,35,38]$ and maximum stress in bending $[29,36,38]$, while the results of the studies conducted so far clearly confirm the influence of the water content and the internode on the values of these strength parameters $[27,29,34,35]$.

Artificial neural network (ANN) is a robust data-modeling tool that is widely used in many applications, such as regression, classification and approximation-based learning processes. Implementation of artificial neural networks for different research proved to be very efficient and accurate. ANNs are characterized by very high accuracy in comparison with other models in certain applications [39-45].

ANNs are used in various scientific fields, including bioinformatics, biochemistry, medicine, meteorology, economic sciences, robotics, aquaculture, food security and climatology. An example of that is the use of ANNs to approximate the gas volumetric percentage in a gas-oil two phase flow [46]. Multilayer perceptron type ANNs have been used as well to enhance the spatial resolution in detector modules constituting the PET (positron emission tomography) scanner [47]. Artificial neural networks are also used in agriculture, agrophysics or agricultural engineering [16,40,41,43-45,48-56].

Many ANN applications are related to renewable energy sources (different uses of ANN models for better energy production predictions). Research addresses, for example, the use of ANNs to forecast solar radiation (the main problem for the best use of photovoltaic systems) and wind power forecasting [57-61].

In the field of engineering, ANN was used, among others, to detect accidental damage to the support bearings on the assembly conveyor [62] and to predict tool wear and surface roughness during turning [63]. Several papers have used ANNs to predict paper properties in order to achieve a high-performance process [64].

There are many uses of artificial neural networks in agriculture [49]. The multilayer perceptron neural network was developed to predict the normalized shear strength of organic soils without drainage [65]. ANNs are also employed to control and predict variables in agricultural drying processes, e.g., to identify the dynamics of said processes for tomato, tobacco and willow woodchips $[45,66]$. Feed-forward artificial neural networks were used to predict energy consumption in closed production plant systems [67]. One very important application area of artificial neural networks in agriculture is the modeling of the greenhouse environment (the greenhouse system is non-linear and variable with time) [68]. Many greenhouse environment predictive models [49,69-73], as well as greenhouse environment and greenhouse energy consumption control systems [74-76], have been developed. 
The diversification of artificial neural networks applications is large, demonstrating the importance of this tool. They achieve high accuracy, are computationally efficient, and require no knowledge of the physical relationships between inputs and outputs [16,42-45,49,77-81].

The aim of the paper was to develop neural models enabling the determination of biomechanical parameters for giant miscanthus stems.

In the literature no information has been found on the creation of neural models for determining biomechanical parameters of plant stems, so our approach is innovative.

\section{Materials and Methods}

\subsection{Gathering Experimental Data}

The plant material used for the research (miscanthus stalks) was harvested in February and March. Samples were taken from individual internodes of miscanthus stalks (Figure 1a), then, the dimensions of the cross-section for each sample were determined (Figure 1b) and subjected to three-point bending strength tests (Figure 1c). Three-point bending tests were carried out in the laboratory of the Department of Mechanical Engineering and Agrophysics. The water content of miscanthus stalks was determined with the drying method, independently for each internode.

The static three-point bending test was used to determine the bending strength parameters of the miscanthus stem. The elliptical shape of the miscanthus stalk cross-section was adopted.

The modulus of elasticity for bending $\left(\mathrm{MOE}_{\text {bend }}\right)$ and maximum stress in bending $\left(\sigma_{\text {bend }}\right)$ for miscanthus stem was calculated from the equations:

$$
\begin{gathered}
\mathrm{MOE}_{\text {bend }}=\frac{\Delta \mathrm{F}_{\text {bend }} \cdot \mathrm{L}^{3}}{48 \cdot \mathrm{I}_{\text {major }} \cdot \Delta \mathrm{f}}=\frac{\left(\mathrm{F}_{\text {bend2 }}-\mathrm{F}_{\mathrm{bend} 1}\right) \cdot \mathrm{L}^{3}}{12 \cdot \pi \cdot\left(\mathrm{f}_{2}-\mathrm{f}_{1}\right) \cdot\left(\mathrm{a}^{3} \cdot \mathrm{b}-\mathrm{a}_{1}^{3} \cdot \mathrm{b}_{1}\right)} \\
\sigma_{\text {bend max }}=\frac{\mathrm{M}_{\text {bendmax }} \cdot \mathrm{a}}{\mathrm{I}_{\text {major }}}=\frac{\mathrm{F}_{\mathrm{bend}} \cdot \mathrm{L} \cdot \mathrm{a}}{\pi \cdot\left(\mathrm{a}^{3} \cdot \mathrm{b}-\mathrm{a}_{1}^{3} \cdot \mathrm{b}_{1}\right)}
\end{gathered}
$$

where:

$\mathrm{MOE}_{\text {bend }}$-modulus of elasticity bending (MPa),

$\Delta \mathrm{F}_{\text {bend }}$ - change in the value of the bending force in the range of the linear characteristic $(\mathrm{N})$,

L-distance between supports ( $\mathrm{mm}$ ),

$\mathrm{I}_{\text {major }}$-moment of inertia around neutral axis (ellipse major axis) $\left(\mathrm{mm}^{4}\right)$,

$\Delta \mathrm{f}-$ the deflection of the stem in the range of the linear characteristic $(\mathrm{mm})$,

$\mathrm{F}_{\mathrm{bend1}}$ - value of the initial bending force $(\mathrm{N})$,

$\mathrm{F}_{\mathrm{bend} 2}$ - value of the main bending force $(\mathrm{N})$,

$\mathrm{f}_{1}$-initial deflection of the stem $(\mathrm{mm})$,

$\mathrm{f}_{2}$-stem deflection for $\mathrm{F}_{\mathrm{bend} 2}(\mathrm{~mm})$,

a-the length of the semi-minor axis of the ellipse $(\mathrm{mm})$,

$\mathrm{b}$ - the length of the semi-major axis of the ellipse $(\mathrm{mm})$,

$\mathrm{a}_{1}$-the semi-minor axis of the ellipse a minus the stalk wall thickness $\mathrm{g}(\mathrm{mm})$,

$b_{1}$-the semi-major axis of the ellipse $b$ minus the stalk wall thickness $g(\mathrm{~mm})$.

$\sigma_{\text {bend max }}$ - maximum stress in bending (MPa),

$\mathrm{M}_{\text {bendmax }}$-maximum bending moment about neutral axis (N.mm),

$\mathrm{I}_{\text {major }}$-moment of inertia around neutral axis (ellipse major axis), $\left(\mathrm{mm}^{4}\right)$,

$\mathrm{F}_{\text {bend }}-$ maximum bending force value $(\mathrm{N})$.

The static three-point bending tests of the stalks were performed in replicates of 15 for each of the five internodes and for each of the two humidities. 


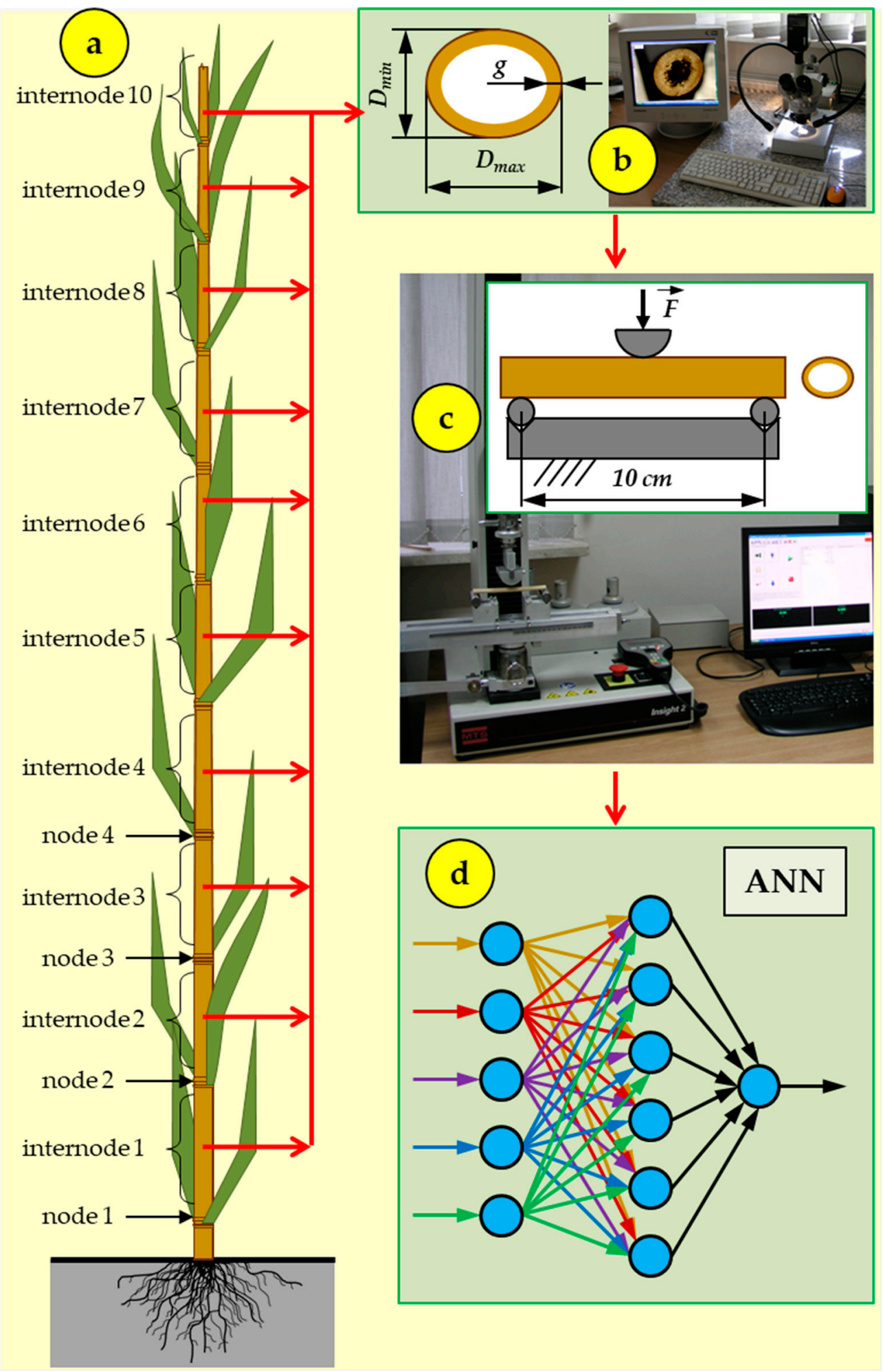

Figure 1. Diagram of the performed research: (a) Scheme of miscanthus stem and internodes from which the samples were taken; (b) stand for determining the characteristic dimensions of samples: $D_{\text {min }}$-minimum stalk diameter, $D_{\max }$-maximum stalk diameter and $g$-stalk wall thickness; (c) a scheme of a three-point bending test; (d) development of artificial neural networks. 


\subsection{Semantic Models Formulation}

The creation of an ANN model begins with adopting a semantic-conceptual model. Such a model should be logically resemble to the theory describing modeled phenomenon in the form of a system of objects and relations between them.

In the case of models using artificial neural networks, the development of a semantic model requires the selection of independent variables (network inputs) and dependent variable or variables (network outputs). If the goal is to determine the value of several dependent variables, better results are obtained by developing several neural models (one ANN for each variable) than one model with several outputs.

In this study, we assumed the modulus of elasticity bending and maximum stress in bending as the dependent variables (biomechanical parameters characterizing the strength of the miscanthus stem).

As independent variables (inputs of the neural network), we assumed water content Wcont, internode number NrNod, maximum bending force value $F_{\text {bend }}$ and dimensions characterizing the cross-section of miscanthus stem: maximum stem diameter $\mathrm{D}_{\text {stem Max }}$ minimum stem diameter $\mathrm{D}_{\text {stem min }}$ and stem wall thickness $\mathrm{Th}_{\text {stem wall }}$.

Four semantic models were formulated:

$$
\begin{gathered}
\text { Model A: } \mathrm{MOE}_{\text {bend }}=f\left(\text { Wcont, NrNod, } \mathrm{D}_{\text {stem Max }}, \mathrm{D}_{\text {stem min }}, \mathrm{Th}_{\text {stem wall }}\right), \\
\text { Model B: } \sigma_{\text {bend }}=f\left(\text { Wcont, NrNod, } \mathrm{D}_{\text {stem Max }}, \mathrm{D}_{\text {stem min }}, \mathrm{Th}_{\text {stem wall }}\right), \\
\text { Model C: MOE } \mathrm{bend}_{\text {ben }}=f\left(\mathrm{Wcont}, \mathrm{NrNod}, \mathrm{D}_{\text {stem Max }}, \mathrm{D}_{\text {stem min }}, \mathrm{Th}_{\text {stem wall }}, \mathrm{F}_{\text {bend }}\right), \\
\text { Model D: } \sigma_{\text {bend }}=f\left(\text { Wcont, NrNod, } \mathrm{D}_{\text {stem Max }}, \mathrm{D}_{\text {stem min }}, \mathrm{Th}_{\text {stem wall }}, \mathrm{F}_{\text {bend }}\right),
\end{gathered}
$$

where:

$\mathrm{MOE}_{\text {bend }}$-modulus of elasticity bending (MPa),

$\sigma_{\text {bend }}$-maximum stress in bending $(\mathrm{MPa})$,

Wcont-water content $\left(\mathrm{kg}_{\text {water }} \cdot \mathrm{kg}_{\text {dry mass }}{ }^{-1}\right)$,

NrNod-internode number (-),

$\mathrm{D}_{\text {stem Max }}$-maximum stem diameter $(\mathrm{mm})$,

$\mathrm{D}_{\text {stem min }}-$ minimum stem diameter $(\mathrm{mm})$,

$\mathrm{Th}_{\text {stem wall }}$-stem wall thickness $(\mathrm{mm})$,

$\mathrm{F}_{\text {bend }}-$ maximum bending force value $(\mathrm{N})$.

Semantic models A and B allow one to determine the values of the modulus of elasticity bending and maximum stress in bending without performing a three-point bending test. However, an additional variable introduced in models $\mathrm{C}$ and $\mathrm{D}\left(\mathrm{F}_{\text {bend }}-\right.$ maximum bending force value) requires an endurance test.

\subsection{Selecting Neural Network's Type and Carrying Out the Process of Learning}

In preliminary studies, the accuracy of models using two different types of feedforward ANNs-multilayer radial basis function networks and multilayer perceptron neural networks (MLP) networks were checked. As MLP networks demonstrated much greater accuracy in further research, only this type of network was used.

The number of neurons in the input and output layers is determined by the number of inputs and outputs from the neural network. In our research, the number of neurons in the input layer was 5 (for models A and B) and 6 (for models C and D), while there was 1 neuron in the output layer. The number of neurons in the hidden layer was changed from 3 to 11 in the course of a repeated process of network learning.

The development of neural models was performed using the specialized software Statistica Neural Networks (Dell Inc. (2016). Dell Statistica (data analysis software system), version 13, StatSoft, Inc., Tulsa, OK, USA). To obtain as accurate models as possible, we applied the procedure of multiple repeats using the function "Automatic Designer". Such 
a procedure allows for obtaining accurate neural models, as the ANN learning process is stochastic.

For each of the four semantic models (Equations (3)-(6)), 100 ANNs with different architectures were developed, with the 10 most accurate networks for each of the four semantic models retained for further analysis.

The entire data set obtained from the measurements, consisting of 1050 patterns (7 water content, 10 internodes and 15 repetitions for each Wcont value and each internode) was randomly divided into learning, testing and validation subsets.

The learning subset is used to create neural models in the ANNs' learning process. The other two subsets are not used in the learning process. The test subset is used to select the best ANNs, while the validation subset is used to assess the ability to generalize the acquired knowledge by the ANN-it allows one to assess the accuracy of the neural network for completely new data.

The division was carried out for groups of measurements-for the individual values of Wcont and NrNod (Figure 2), assuming that 70\% are learning subset, $15 \%$ testing subset and $15 \%$ validation subset:

- $\quad$ learning subset: Wcont $=0.219(\operatorname{NrNod}=1,2,4,7,9)$; Wcont $=0.226(\operatorname{NrNod}=1,2,4$, $5,6,8,9)$; Wcont $=0.298(\operatorname{NrNod}=1,4,5,6,7,8,10) ;$ Wcont $=0.388(\operatorname{NrNod}=1,2,3,4$, $5,7,8,9,10)$; Wcont $=0.412(\operatorname{NrNod}=1,2,3,6,8,9)$; Wcont $=0.470(\operatorname{NrNod}=1,2,3,5$, $6,8,9,10)$; Wcont $=0.481(\operatorname{NrNod}=1,2,3,5,6,8,9,10)$;

- $\quad$ testing subset: $\mathrm{Wcont}=0.219(\mathrm{NrNod}=3,6,8) ; \mathrm{W}$ cont $=0.226(\mathrm{NrNod}=3) ; \mathrm{Wcont}=0.388$ $(\mathrm{NrNod}=6) ; \mathrm{Wcont}=0.412(\mathrm{NrNod}=4,5,7) ; \mathrm{Wcont}=0.470(\mathrm{NrNod}=4,7)$;

- $\quad$ validation subset: $\mathrm{Wcont}=0.219(\mathrm{NrNod}=5) ; \mathrm{Wcont}=0.226(\mathrm{NrNod}=7,10)$; Wcont $=0.298(\mathrm{NrNod}=2,3,9) ; \mathrm{Wcont}=0.412(\mathrm{NrNod}=10) ; \mathrm{Wcont}=0.481(\mathrm{NrNod}=4,7)$.

\begin{tabular}{|c|c|c|c|c|c|c|c|c|c|c|c|}
\hline & 1 & & Int & ern & ode & 6 & 7 & $\begin{array}{l}\text { ber } \\
8 \\
\end{array}$ & 1 & \\
\hline \multirow{7}{*}{ 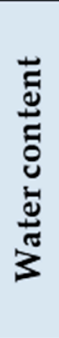 } & 0.219 & $\mathrm{~L}$ & $\begin{array}{ll}\mathrm{L} \\
\end{array}$ & $\mathrm{T}$ & $\mathrm{L}$ & $\mathbf{V}$ & $\mathrm{T}$ & $\mathbf{L}$ & $\mathrm{T}$ & & \\
\hline & 0.226 & L & L & $\mathrm{TT}$ & $\mathbf{L}$ & $\mathbf{L}$ & $\mathbf{L}$ & $\mathbf{V}$ & $\mathbf{L}$ & & V \\
\hline & 0.298 & L & $\mathbf{V}$ & $\mathbf{V}$ & L & L & $\mathrm{L}$ & L & L & \begin{tabular}{l|l}
$\mathbf{V}$ & 1 \\
\end{tabular} & $\mathbf{L}$ \\
\hline & 0.388 & $\mathrm{~L}$ & $\mathrm{~L}$ & $\mathrm{~L}$ & $\mathrm{~L}$ & $\mathrm{~L}$ & $\mathrm{~T}$ & $\mathrm{~L}$ & $\mathrm{~L}$ & \begin{tabular}{l|l}
$\mathbf{L}$ & 1 \\
\end{tabular} & $\mathrm{~L}$ \\
\hline & 0.412 & $\mathrm{~L}$ & $\mathbf{L}$ & $\mathrm{L}$ & $\mathrm{T}$ & $\mathrm{T}$ & $\mathbf{L}$ & 1 & $\mathbf{L}$ & \begin{tabular}{l|l}
$\mathrm{L}$ & $\mathrm{I}$ \\
\end{tabular} & $\mathbf{V}$ \\
\hline & 0.470 & L & $\mathbf{L}$ & $\mathrm{L}$ & 1 & $\mathrm{~L}$ & $\mathbf{L}$ & T & $\mathbf{L}$ & $\begin{array}{l}\mathrm{L} \\
\end{array}$ & $\mathbf{L}$ \\
\hline & 0.481 & L & $\mathrm{L}$ & $\mathbf{L}$ & $\checkmark$ & $\mathrm{L}$ & $\mathrm{L}$ & V & L & $\begin{array}{lll}\mathrm{L} & 1\end{array}$ & \\
\hline
\end{tabular}

Figure 2. Division of data into individual subsets: L-learning subset; T-testing subset; Vvalidation subset.

In the learning process, four different activation functions were used: linear, logistic, hyperbolic tangent and exponential. The BFGS (Broyden-Fletcher-Goldfarb-Shanno) algorithm was used in the learning process. The BFGS algotithm is a quasi-Newton optimization method, which provides good convergence and is the most recommended technique for training neural networks [82-84].

\subsection{Choosing and Assessing the Best Neural Models}

As the criterion for selecting the best ANN, the value of root mean-square error (RMSE) was selected for testing the data subset, independently for the four adopted semantic models, calculated according to the formula:

$$
\operatorname{RMSE}=\sqrt{\frac{1}{n} \sum_{i=1}^{n}\left(Y_{M E, i}-Y_{A N N, i}\right)^{2}}
$$


where:

RMSE-root mean-square error $(\mathrm{MPa})$,

$Y_{M E, i}$ - measured value of output $(\mathrm{MPa})$,

$Y_{A N N, i}$ - calculated by ANN value of output (MPa),

$n$-number of observations (-).

RSME is a commonly used statistical error to evaluate the model's performance $[54,73,75,85]$.

For the analysis of selected neural models, the mean absolute percentage error (MAPE) was used:

$$
\mathrm{MAPE}=\frac{1}{n} \sum_{i=1}^{n}\left|\frac{Y_{M E, i}-Y_{A N N, i}}{Y_{M E, i}}\right| \cdot 100 \%
$$

where:

MAPE—-mean absolute percentage error (\%),

| ... | -absolute value (-).

$Y_{M E, i}-$ measured value of output $(\mathrm{MPa})$,

$Y_{A N N, i}$ - calculated by ANN value of output (MPa),

$n$-number of observations (-).

In order to evaluate the assumed independent variables in the semantic models, a sensitivity analysis was performed for selected neural models. Sensitivity analysis, based on the value of the error quotient, allows one to determine which variables in the model are important for its accuracy. The greater the value of this quotient, the more important the input field is for the accuracy of the model.

\section{Results}

Figures 3-6 summarize the RMSE values for all developed neural networks for the testing subsets. Based on these values, the best neural networks were selected. RMSE values for all subsets of data (learning, testing and validation) are provided in Appendix A (Figures A1-A4).

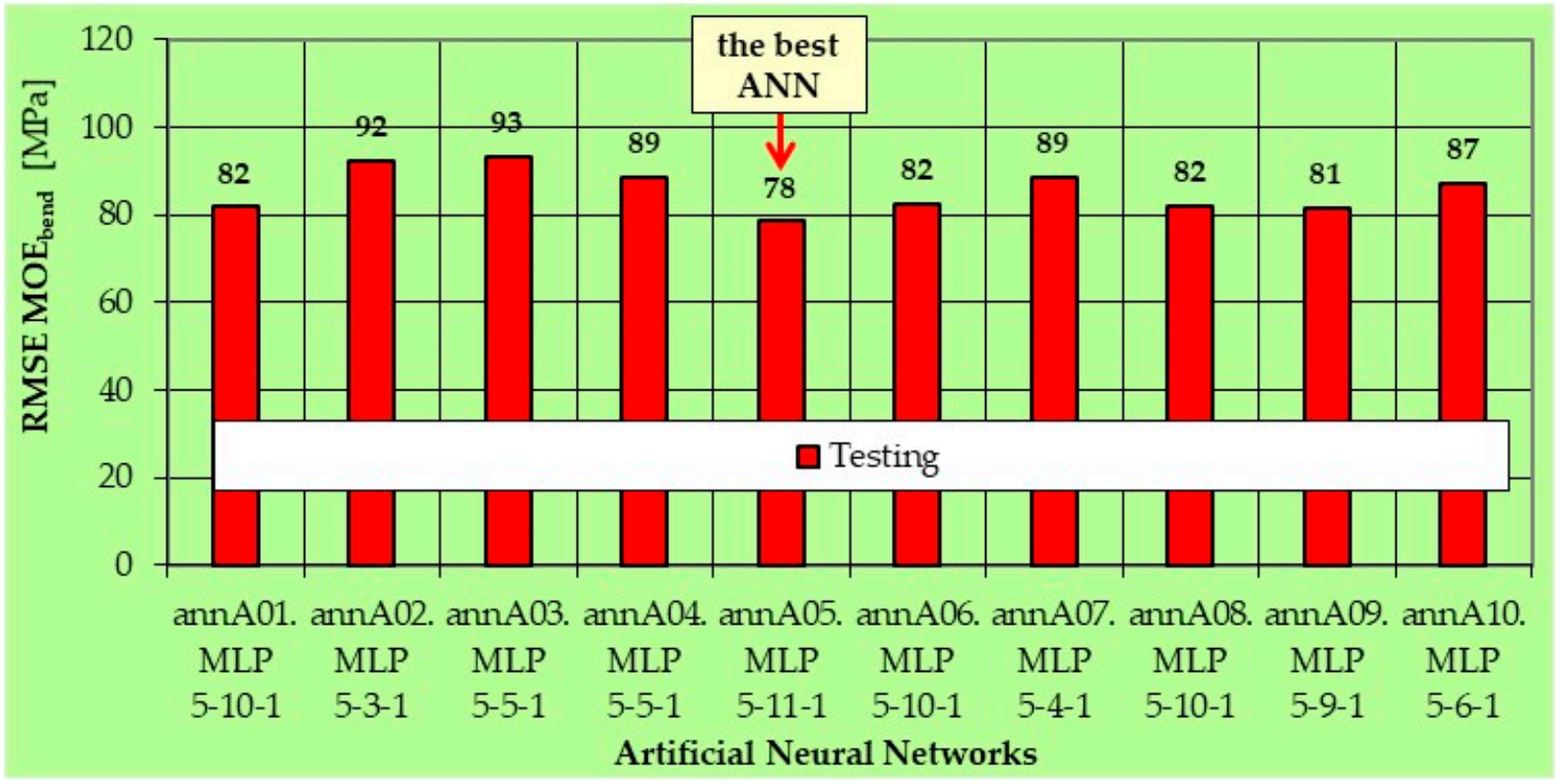

Figure 3. RMSE error values for the $\mathrm{MOE}_{\text {bend }}$ dependent variable, for the semantic model A (ANN with 5 inputs) for the testing data subset. 


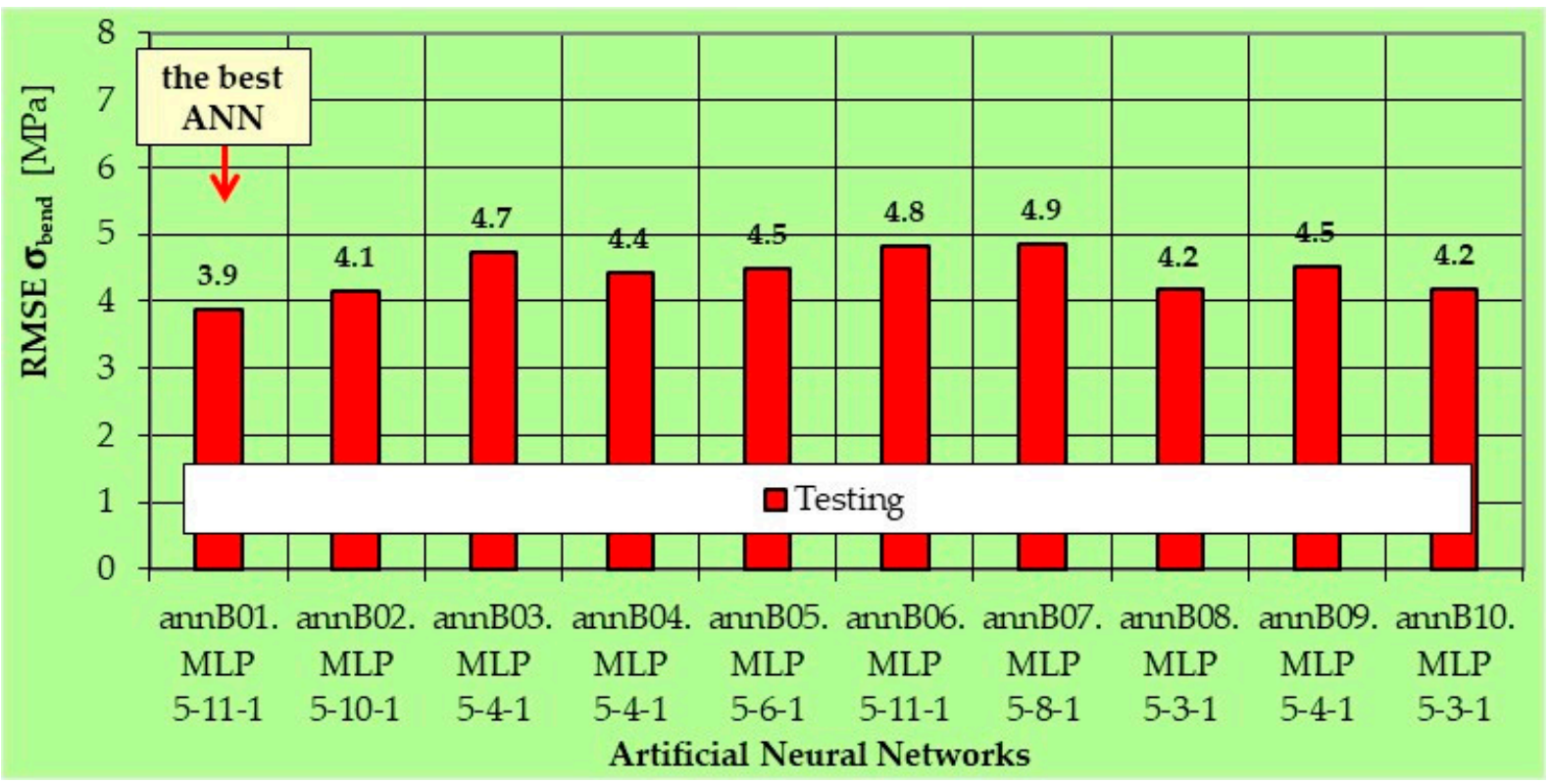

Figure 4. RMSE error values for the $\sigma_{\text {bend }}$ dependent variable, for the semantic model B (ANN with 5 inputs) for the testing data subset.

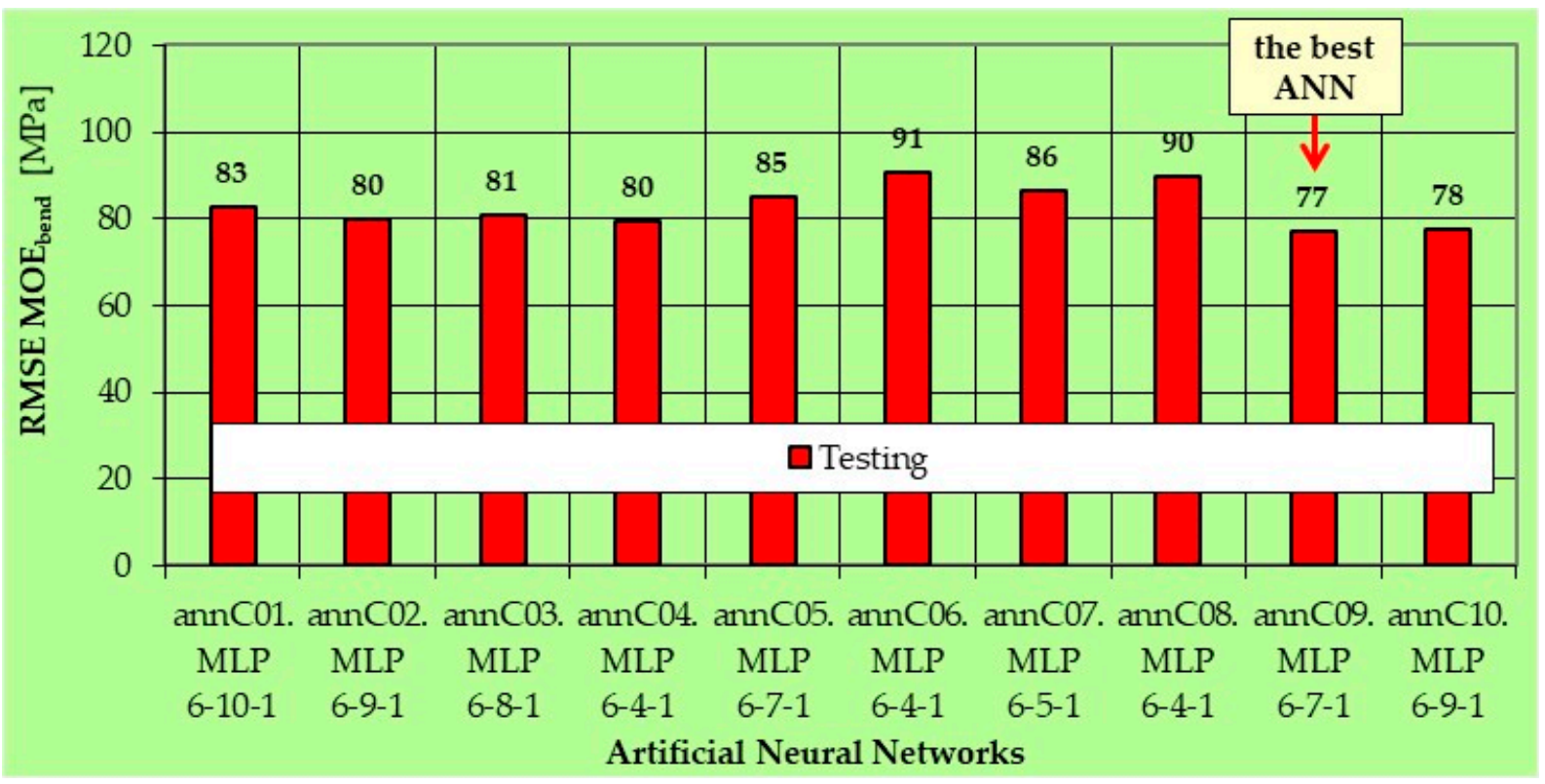

Figure 5. RMSE error values for the $\mathrm{MOE}_{\mathrm{bend}}$ dependent variable, for the semantic model C (ANN with 6 inputs) for the testing data subset.

For the $\mathrm{MOE}_{\text {bend }}$ variable, for the testing subset, the smallest RMSE error value $=78 \mathrm{MPa}$ was calculated for the annA05 MLP 5-11-1 neural network (Figure 3). For $\sigma_{\text {bend }}$, the smallest error for the testing subset (RMSE $=3.9 \mathrm{MPa}$ ) was calculated for the annB01 MLP 5-11-1 network (Figure 4). For the neural networks developed in accordance with the $\mathrm{C}$ semantic model, the lowest $\mathrm{RMSE}$ value $=77 \mathrm{MPa}$ for the testing subset was obtained for annC09 MLP 6-7-1 (Figure 5). The developed neural networks in accordance with the semantic model $\mathrm{D}$, which allow for the determination of $\sigma_{\text {bend }}$, achieved very high accuracy. The minimum RMSE error value $=0.20 \mathrm{MPa}$ (for the testing subset) had annD03 MLP 6-10-1 (Figure 6). The above neural networks were selected as the best and subjected to further analysis. 


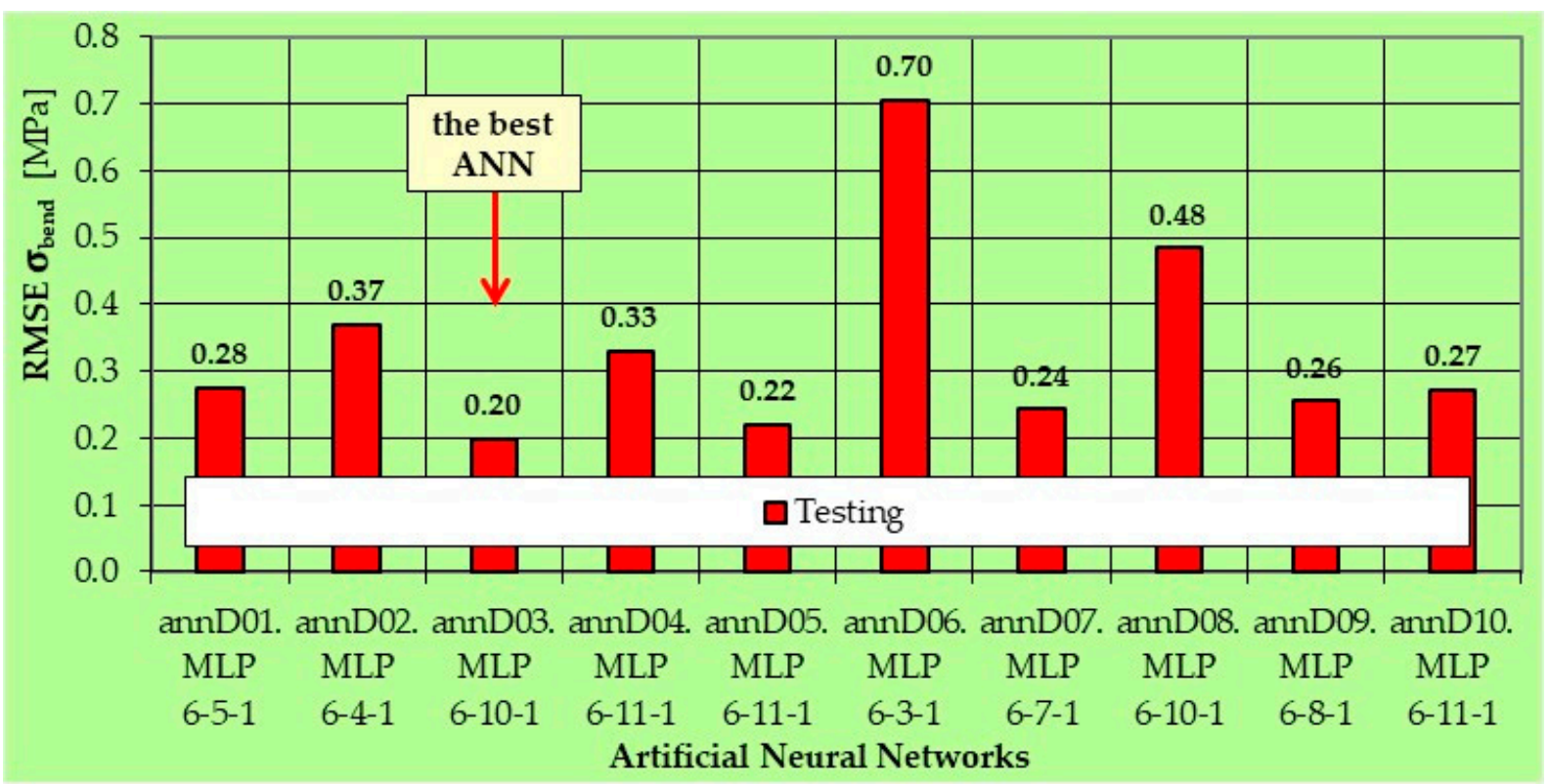

Figure 6. RMSE error values for the $\sigma_{\text {bend }}$ dependent variable, for the semantic model B (ANN with 6 inputs) for the testing data subset.

Figure 7 summarizes the MAPE error values for the selected four best neural models for the learning, testing and validation data subsets. MAPE values for all developed neural networks are included in Appendix B (Figures A5-A8).

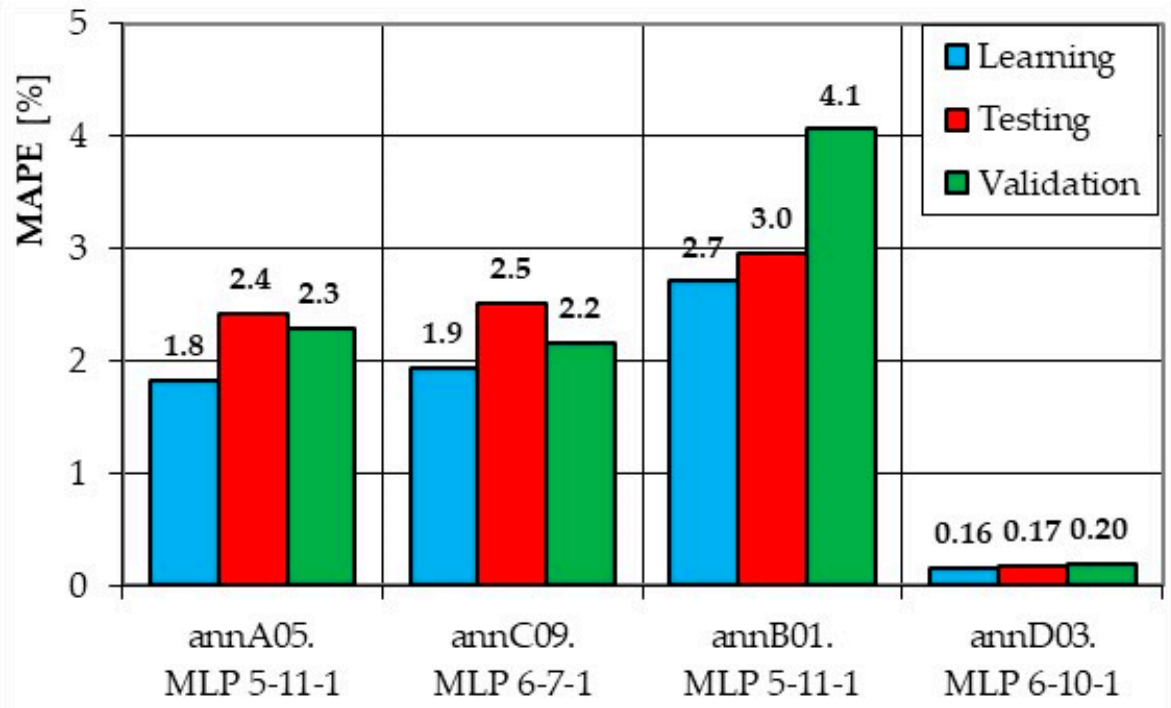

Artificial Neural Networks

Figure 7. MAPE error values for the best ANNs for the learning, testing and validation data subsets.

The sensitivity analysis results for selected neural networks annA05, annB01, annC09 and annD03 are presented in Tables 1 and 2 (for validation subset). Error ratio values (greater than 1) indicate that all adopted semantic models A, B, C and D are correct. 
Table 1. Sensitivity analysis for selected neural models annA05 and annB051 for validation data subset.

\begin{tabular}{|c|c|c|c|c|c|c|}
\hline \multirow{2}{*}{$\begin{array}{c}\text { Dependent Variable } \\
\text { ANN Model }\end{array}$} & & \multicolumn{5}{|c|}{ Independent Variables (ANN Inputs) } \\
\hline & & Wcont * & NrNod * & $\mathrm{D}_{\text {stem Max }} *$ & $\mathrm{D}_{\text {stem min }} *$ & $\mathrm{Th}_{\text {stem wall }}$ * \\
\hline $\begin{array}{c}\text { MOE }_{\text {bend }} \\
\text { annA05 } \\
\text { (MLP 5-11-1) }\end{array}$ & $\begin{array}{l}\text { Error quotient } \\
\text { rank }\end{array}$ & $\begin{array}{c}4.3 \\
3\end{array}$ & $\begin{array}{c}1.8 \\
5\end{array}$ & $\begin{array}{c}2.6 \\
4\end{array}$ & $\begin{array}{c}8.3 \\
1\end{array}$ & $\begin{array}{c}6.5 \\
2\end{array}$ \\
\hline $\begin{array}{c}\sigma_{\text {bend }} \\
\text { annB01 } \\
(\text { MLP 5-11-1) }\end{array}$ & $\begin{array}{l}\text { Error quotient } \\
\text { rank }\end{array}$ & $\begin{array}{c}8.7 \\
3\end{array}$ & $\begin{array}{c}4.7 \\
5\end{array}$ & $\begin{array}{c}6.0 \\
4\end{array}$ & $\begin{array}{c}8.9 \\
2\end{array}$ & $\begin{array}{c}19.7 \\
1\end{array}$ \\
\hline
\end{tabular}

${ }^{*}$ Wcont—water content $\left(\mathrm{kg}_{\text {water }} \cdot \mathrm{kg}_{\text {dry mass }}{ }^{-1}\right)$, NrNod-internode numer (-), $\mathrm{D}_{\text {stem Max }}$-maximum stem diameter $(\mathrm{mm}), \mathrm{D}_{\text {stem } \min }$ - minimum stem diameter $(\mathrm{mm})$ and $\mathrm{Th}_{\text {stem wall }}$-stem wall thickness $(\mathrm{mm})$.

Table 2. Sensitivity analysis for selected neural models, annC09 and annD03, for the validation data subset.

\begin{tabular}{|c|c|c|c|c|c|c|c|}
\hline \multirow{2}{*}{$\begin{array}{c}\text { Dependent } \\
\text { Variable } \\
\text { ANN Model }\end{array}$} & \multicolumn{7}{|c|}{ Independent Variables (ANN Inputs) } \\
\hline & & Wcont * & NrNod * & $\mathrm{D}_{\text {stem Max }}$ * & $\mathrm{D}_{\text {stem min }}$ * & $\mathrm{Th}_{\text {stem wall }}{ }^{*}$ & $\mathrm{~F}_{\text {bend Max }}$ * \\
\hline $\mathrm{MOE}_{\text {bend }}$ & $\begin{array}{c}\text { Error } \\
\text { quotient }\end{array}$ & 2.4 & 3.1 & 1.3 & 5.5 & 2.2 & 2.6 \\
\hline (MLP 6-7-1) & rank & 4 & 2 & 6 & 1 & 5 & 3 \\
\hline $\begin{array}{c}\sigma_{\text {bend }} \\
\text { annD03 }\end{array}$ & $\begin{array}{c}\text { Error } \\
\text { quotient }\end{array}$ & 3.3 & 9.7 & 4826 & 11,964 & 7021 & 29,524 \\
\hline (MLP 6-10-1) & rank & 6 & 5 & 4 & 2 & 3 & 1 \\
\hline
\end{tabular}

* Wcont-water content $\left(\mathrm{kg}_{\text {water }} \cdot \mathrm{kg}_{\text {dry mass }}{ }^{-1}\right)$, NrNod-internode numer $(-)$, $\mathrm{D}_{\text {stem Max }}$-maximum stem diameter $(\mathrm{mm}), \mathrm{D}_{\text {stem min }}$ - minimum stem diameter $(\mathrm{mm}), \mathrm{Th}_{\text {stem wall }}$-stem wall thickness $(\mathrm{mm})$ and $\mathrm{F}_{\text {bend Max }}$ - maximum bending force value $(\mathrm{N})$.

Table 3 lists the architecture, training algorithm and activation functions of the selected ANNs.

Table 3. Characteristic of selected neural models.

\begin{tabular}{|c|c|c|c|c|c|c|c|}
\hline ANN & $\begin{array}{c}\text { Type and } \\
\text { Architecture } \\
\text { of the } \\
\text { Neural } \\
\text { Network }\end{array}$ & $\begin{array}{l}\text { Neuron } \\
\text { Number } \\
\text { in Input } \\
\text { Layer }\end{array}$ & $\begin{array}{c}\text { Liczba } \\
\text { Neuronów } \\
\text { in Hidden } \\
\text { Layer }\end{array}$ & $\begin{array}{c}\text { Liczba } \\
\text { Neuronów } \\
\text { in Ouput } \\
\text { Layer }\end{array}$ & $\begin{array}{l}\text { Learning } \\
\text { Algorithm }\end{array}$ & $\begin{array}{c}\text { Activation } \\
\text { Function } \\
\text { in Hidden } \\
\text { Layer }\end{array}$ & $\begin{array}{c}\text { Activation } \\
\text { Function } \\
\text { in Ouput } \\
\text { Layer }\end{array}$ \\
\hline annA05 & MLP 5-11-1 & 5 & 11 & 1 & BFGS 170 & Logistic & Exponential \\
\hline annB01 & MLP 5-11-1 & 5 & 11 & 1 & BFGS 178 & Logistic & Exponential \\
\hline annC09 & MLP 6-7-1 & 6 & 7 & 1 & BFGS 82 & Logistic & Exponential \\
\hline annD03 & MLP 6-10-1 & 6 & 10 & 1 & BFGS 237 & Logistic & Linear \\
\hline
\end{tabular}

BFGS-Broyden-Fletcher-Goldfarb-Shanno algorithm; MLP—-multilayer perceptron.

Figures 8 and 9 show the MAPE error values for selected (best) models developed in accordance with the semantic models A, B, C and D (annA05, annC09, annB01 and annD03), for validation subsets. MAPE errors were calculated for individual measurement conditions-for the set levels of the independent variables Wcont and NrNod. 


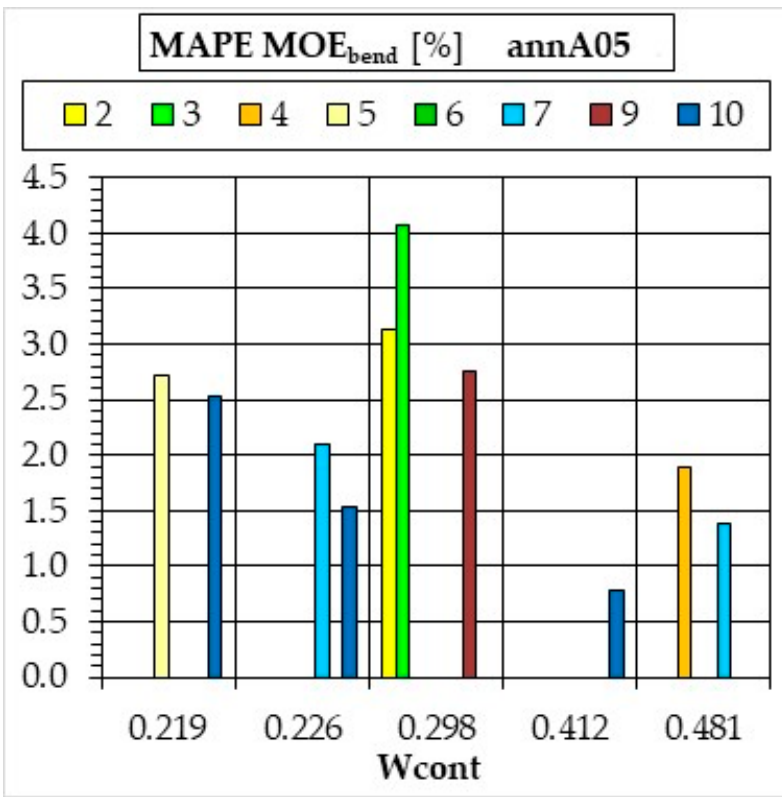

(a)

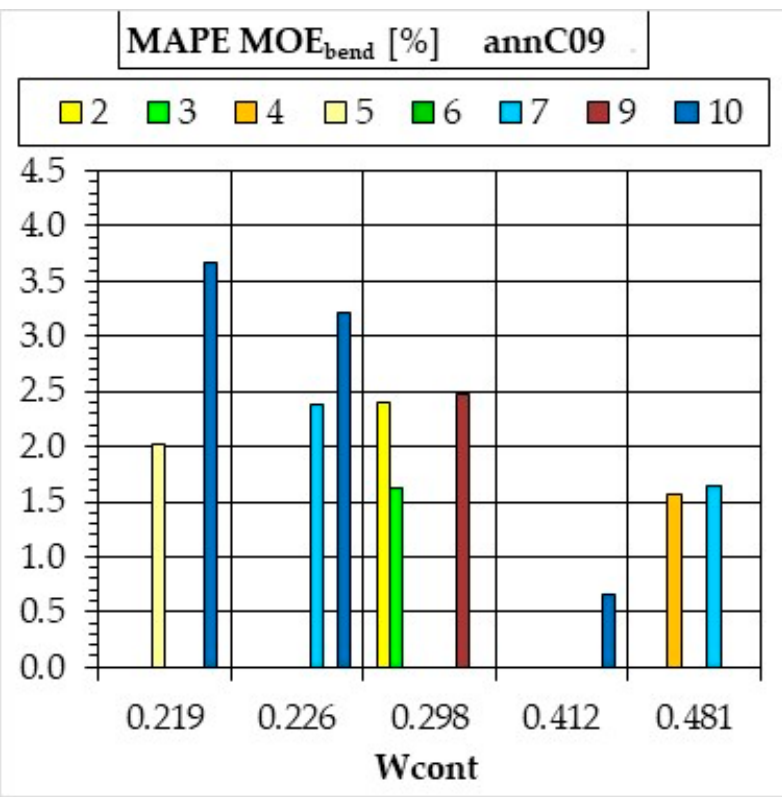

(b)

Figure 8. MAPE error values for the $\mathrm{MOE}_{\text {bend }}$ dependent variable and for the validation data subset, depending on the internode number (NrNod) and water content (Wcont): (a) for annA05 (MLP 5-11-1); (b) for annC09 (MLP 6-7-1).

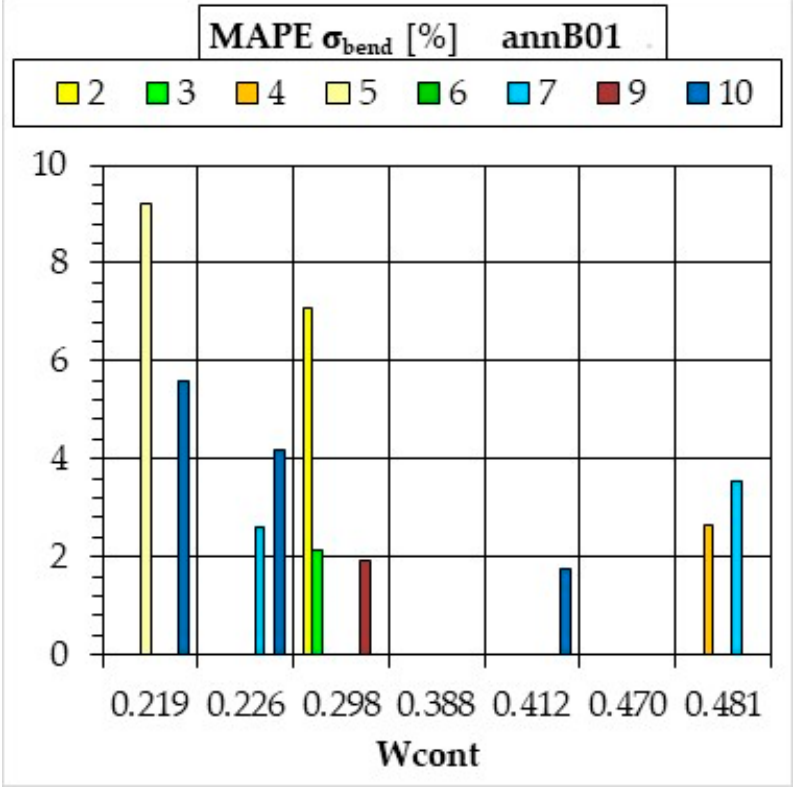

(a)

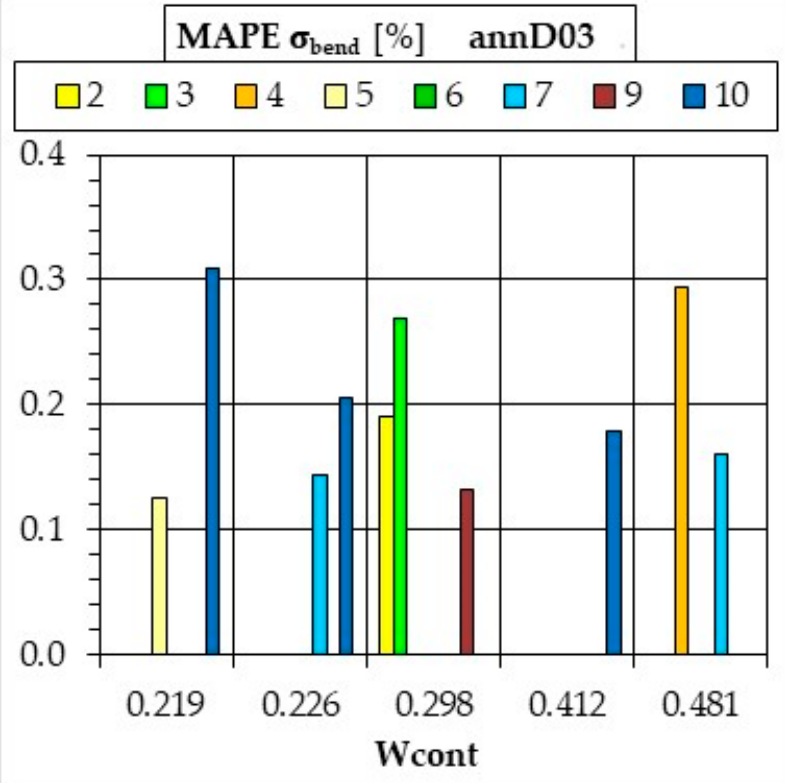

(b)

Figure 9. MAPE error values for the $\sigma_{\text {bend }}$ dependent variable and for the validation data subset, depending on the internode number (NrNod) and water content (Wcont): (a) for annB01 (MLP 5-11-1); (b) for annD03 (MLP 6-10-1).

In Appendix C (Figures A9-A12), MAPE error values for all data subsets (learning, testing and validation) were compiled. 


\section{Discussion}

Based on the conducted sensitivity analysis, it was demonstrated that four semantic models were correctly adopted-all input variables are important for the accuracy of selected neural models (annA05, annB01, annC09 and annD03).

For the annA05 network, which enables the determination of modulus of elasticity in bending $\left(\mathrm{MOE}_{\text {bend }}\right)$ value, the values of the error quotient (Table 1) demonstrated that the most important inputs of the neural network are the minimum diameter of the stalk $\left(\mathrm{D}_{\text {stem min }}\right)$ and the thickness of the stalk wall $\left(\mathrm{Th}_{\text {stem wall }}\right)$.

For the annC09 network (Table 2), the most important inputs of the neural network are the minimum diameter of the stalk $\left(\mathrm{D}_{\text {stem min }}\right)$. The internode number $(\mathrm{NrNod})$ came second, and the maximum bending force $\left(\mathrm{F}_{\text {bend Max }}\right)$ came third as an additional network input compared to annA05.

A slightly different ranking of the neural network inputs occurred in the case of the annB01 model (Table 1), which made it possible to determine the maximum bending stress $\left(\sigma_{\text {bend }}\right)$. The most important input (the highest value of the error quotient) is the stalk wall thickness $\left(\mathrm{Th}_{\text {stem wall }}\right)$, followed by the minimum diameter of the stalk $\left(\mathrm{D}_{\text {stem min }}\right)$ and the water content (Wcont).

However, for the annD03 model, in which the maximum bending force was introduced as an additional network input, the ranking of the inputs is also different (Table 2). The first is $F_{\text {bend Max }}$, with 2.5 times the error quotient value compared to the second $D_{\text {stem min }}$, and about four times greater than the third $\mathrm{D}_{\text {stem Max }}$. NrNod and Wcont, which are fifth and sixth in the ranking and have error quotient values several thousand times lower than $\mathrm{F}_{\text {bend Max }}$.

Such order is understandable because the geometric dimensions of the cross-section of the stalk, which is a biocomposite pipe with an oval cross-section, determine the value of the moment of inertia that is used to calculate the modulus of elasticity and the maximum bending stress $\left(\sigma_{\text {bend }}\right)$. The value of $F_{\text {bend Max }}$ appears in the formula for calculating $\sigma_{\text {bend }}$. The significant influence of NrNod on the value of $\mathrm{MOE}_{\mathrm{bend}}$ may result from the fact that the internodes are formed by the miscanthus gradually, from the lowest to the highest. On the other hand, the influence of water content on biomechanical parameters of plants has been demonstrated in many studies.

Neural networks used to determine $\mathrm{MOE}_{\text {bend, }}$ developed in accordance with the semantic models A and C, are characterized by similar accuracy. The MAPE error values are similar for the validation subset: $2.2-2.4 \%$ and $1.9-2.4 \%$ (Appendix B: Figures A5 and A7). The MAPE values for the learning subset are at a similar level, and slightly higher for the testing subset (2.4-2.9\%). The best ANNs selected (annA05 and annC09) have almost identical MAPE error values: $1.8 \%$ and $1.9 \%$ for the learning subset, $2.4 \%$ and $2.5 \%$ for the testing subset, and $2.3 \%$ and $2.2 \%$ for the validation subset (Figure 7 ).

Taking into account such small differences in errors between these ANNs and the fact that with the annC09 model it is necessary to carry out an endurance test in order to determine the $\mathrm{F}_{\text {bend Max }}$ value, the annA05 network is the more appropriate one. To determine the $\mathrm{MOE}_{\mathrm{bend}}$ value with similar accuracy, annA05 requires only knowledge of the dimensions of the stalk cross-sectional dimensions, internode number and water content.

In the case of neural models used to determine the $\sigma_{\text {bend }}$ value (developed in accordance with the B and D semantic models), the differences in the MAPE error values are much greater.

For B-type neural networks, the MAPE error for the validation subset varies from 3.7\% to $4.7 \%$ and for D models it is about 10 times smaller-from $0.20 \%$ to $0.44 \%$ (Appen-dix B: Figures A6 and A8). The best-selected models (annB01 and annD03) have MAPE error values of $2.7 \%$ and $0.16 \%$ for the learning subset, $3.0 \%$ and $0.17 \%$ for the testing subset and $4.1 \%$ and $0.20 \%$ for the validation subset (Figure 7 ). 
Such significant differences in the error values between the annB01 and annD03 networks mean that the annD03 network is the recommended model for determining the $\sigma_{\text {bend }}$ value, despite the need to perform a bending test.

Figures 8 and 9 enable detailed MAPE error analysis for selected models (annA05, annC09, annB01 and annD03), for validation data subset. The MAPE values calculated for individual Wcont and NrNod values (measurement conditions) were summarized-in groups of 15 repetitions. It can be determined for which water contents and internode numbers the ANNs are least accurate.

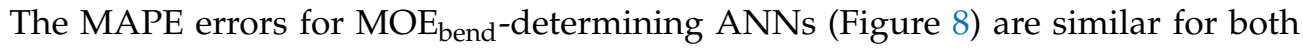
models (annA05 and annC09). In the case of the validation subset, these errors are smaller for high water contents (Wcont $=0.412 \mathrm{~kg}_{\text {water }} \cdot \mathrm{kg}_{\text {dry mass }}{ }^{-1}$ and $0.481 \mathrm{~kg}_{\text {water }} \cdot \mathrm{kg}_{\text {dry mass }}{ }^{-1}$ ). The maximum MAPE for annC09 (3.7\%) is only slightly lower than that for annA05 (4.1\%).

The highest value of MAPE for annA05 occurs for $\mathrm{NrNod}=3$ and Wcont $=0.412$ $\mathrm{kg}_{\text {water }} \cdot \mathrm{kg}_{\text {dry mass }}{ }^{-1}$ (learning subset) and amounts to $6.4 \%$ (Appendix C, Figure A9). In addition, for annC09, the highest value of MAPE occurs for NrNod $=3$ and Wcont $=0.412$ $\mathrm{kg}_{\text {water }} \cdot \mathrm{kg}_{\text {dry mass }}{ }^{-1}$ and amounts to $6.7 \%$ (Appendix C, Figure A11). As there is the same "measuring point", it can be concluded that the increase in error is the result of a particularly large data noise.

The most even distribution of MAPE values occurs for Wcont $=0.388 \mathrm{~kg}_{\text {water }} \cdot \mathrm{kg}_{\text {dry mass }}{ }^{-1}$, for annA05 from $0.7 \%$ to $2.6 \%$ (Appendix C, Figure A11) and for annC09 from $0.9 \%$ to $2.4 \%$ (Appendix C, Figure A11). On the other hand, the least uniform distribution of MAPE values was found for Wcont $=0.412 \mathrm{~kg}_{\text {water }} \cdot \mathrm{kg}_{\text {dry mass }}{ }^{-1}$, for both neural models. The spread of values is almost identical: for annA05 from $0.8 \%$ to $6.4 \%$, and for annC09 from $0.7 \%$ to $6.7 \%$.

The above analysis demonstrates that both developed neural models (annA05 and annC09) are similar in terms of error values for different Wcont and NrNod values. They are most accurate at Wcont $=0.388 \mathrm{~kg}_{\text {water }} \cdot \mathrm{kg}_{\text {dry mass }}{ }^{-1}$, for all internodes.

The MAPE errors for $\sigma_{\text {bend }}$-determining ANNs (Figure 9) are very different for both models (annB01 and annD03). In the case of the validation set, for annB01, these errors are smaller for high water contents (Wcont $=0.412 \mathrm{~kg}$ water $\cdot \mathrm{kg}_{\text {dry mass }}{ }^{-1}$ and $0.481 \mathrm{~kg}_{\text {water }} \cdot \mathrm{kg}_{\text {dry mass }}{ }^{-1}$ ). The maximum MAPE for annB01 is $9.2 \%$ and the lowest is $1.7 \%$ (Figure $9 a$ ). For annD03, the MAPE values are much smaller. For the validation set, the highest value is $0.31 \%$ and the lowest $0.13 \%$ (Figure $9 b$ ).

The highest MAPE value for annB01 occurs for $\mathrm{NrNod}=5$ and Wcont = $0.219 \mathrm{~kg}_{\text {water }} \cdot \mathrm{kg}_{\text {dry mass }}{ }^{-1}$ (validation subset) and amounts to $9.2 \%$ (Appendix C, Figure A10). On the other hand, for annD03, the highest MAPE value occurs for NrNod $=4$ and Wcont $=0.470 \mathrm{~kg}_{\text {water }} \cdot \mathrm{kg}_{\text {dry mass }}{ }^{-1}$ (testing subset) and is $0.33 \%$ (Appendix C, Figure A12).

The most even distribution of MAPE values occurs for Wcont $=0.470 \mathrm{~kg}_{\text {water }} \cdot \mathrm{kg}_{\text {dry mass }}{ }^{-1}$, for annB01 from 2.2\% to 3.7\% (Appendix C, Figure A10), and for Wcont $=0.412 \mathrm{~kg}_{\text {water }}$. $\mathrm{kg}_{\text {dry mass }}{ }^{-1}$, for annD03 from $0.12 \%$ to $0.20 \%$ (Appendix C, Figure A12). On the other hand, the least uniform distribution of MAPE values was found for Wcont $=0.219 \mathrm{~kg}_{\text {water }} \cdot \mathrm{kg}_{\text {dry mass }}{ }^{-1}$, for both neural models. The spread of values is: for annB01 from $2.1 \%$ to $9.2 \%$, and for annD03 from $0.08 \%$ to $3.1 \%$.

\section{Conclusions}

The four developed neural models, enabling the determination of the value of the modulus of elasticity in bending (annA05 and annC09) and the maximum stress in bending (annB01 and annD03), demonstrate sufficient and even very high accuracy. The neural networks, annA05, annC09 and annB01, respectively, have an average relative error of $2.18 \%, 2.21 \%$ and $3.24 \%$ for all data subsets. On the other hand, the average relative error for annD03 is an order of magnitude lower and amounts to $0.18 \%$.

The results of the sensitivity analysis confirmed that all input variables are important for the accuracy of the developed neural models—correct semantic models. 
To determine the $\mathrm{MOE}_{\text {bend }}$ value, we propose the annA05 neural model, which requires only knowledge of the dimensions of the stalk cross-section, internode number and water content (the annC09 model is just as accurate but requires a three-point bending test). However, for the determination of the value of $\sigma_{\text {bend }}$, we propose the neural model annD03, which is about 18 times more accurate than annB01, although it has an additional input variable ( $\mathrm{F}_{\text {bend }}$ obtained from the three-point bending test).

Our further research will be conducted towards increasing the operability of ANNs models used to determine the biomechanical parameters of miscanthus. We will try to develop a tool that will reduce the need to carry out labor-intensive strength tests when determining the $\mathrm{MOE}_{\mathrm{bend}}$ and $\sigma_{\text {bend }}$ values for individual parts of the stem (individual internodes).

Author Contributions: Conceptualization, S.F. and Z.Ś.; methodology, S.F. and B.Ł.-K.; software, S.F. and N.P.; validation, S.F., W.S., R.F. and Z.Ś.; investigation, B.Ł.-K. and R.F.; data curation, S.F. and R.F.; writing-original draft preparation, S.F. and R.F.; writing—review and editing, S.F., B.t.-K., N.P., W.S. and Z.Ś.; visualization, N.P., W.S. and R.F.; supervision, S.F. and B.Ł.-K. All authors have read and agreed to the published version of the manuscript.

Funding: Article processing charges were financed from the subsidy of the Ministry of Education and Science for the Agricultural University of Hugo Kołłataj in Krakow for the year 2022.

Institutional Review Board Statement: Not applicable.

Informed Consent Statement: Not applicable.

Data Availability Statement: Data is contained within the article.

Conflicts of Interest: The authors declare no conflict of interest.

\section{Appendix A}

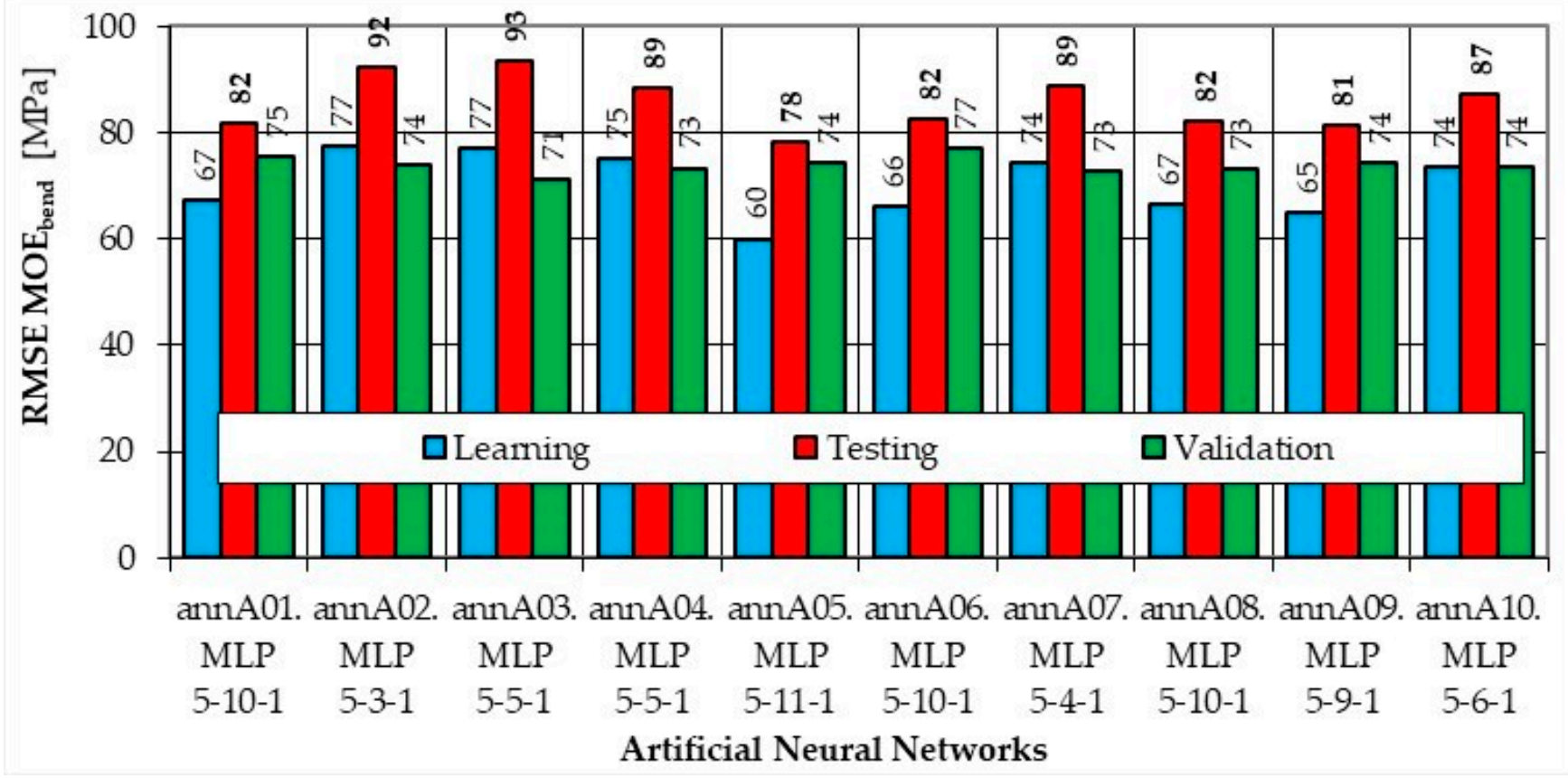

Figure A1. RMSE error values for the $\mathrm{MOE}_{\text {bend }}$ dependent variable, for the semantic model A (ANN with 5 inputs) for the learning, testing and validation data subsets. 


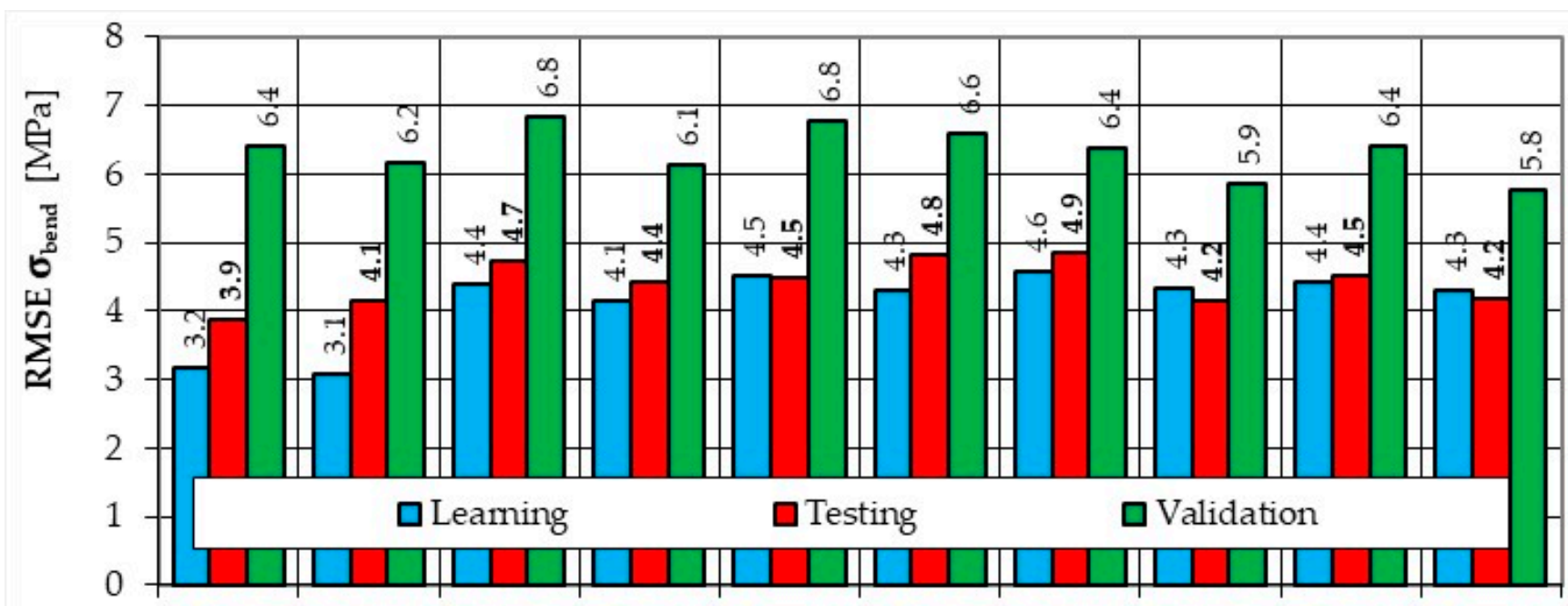

annB01. annB02. annB03. annB04. annB05. annB06. annB07. annB08. annB09. annB10.

\begin{tabular}{cccccccccc} 
MLP & MLP & MLP & MLP & MLP & MLP & MLP & MLP & MLP & MLP \\
$5-11-1$ & $5-10-1$ & $5-4-1$ & $5-4-1$ & $5-6-1$ & $5-11-1$ & $5-8-1$ & $5-3-1$ & $5-4-1$ & $5-3-1$ \\
& & \multicolumn{8}{c}{ Artificial Neural Networks }
\end{tabular}

Figure A2. RMSE error values for the $\sigma_{\text {bend }}$ dependent variable, for the semantic model B (ANN with 5 inputs) for learning, testing and validation data.

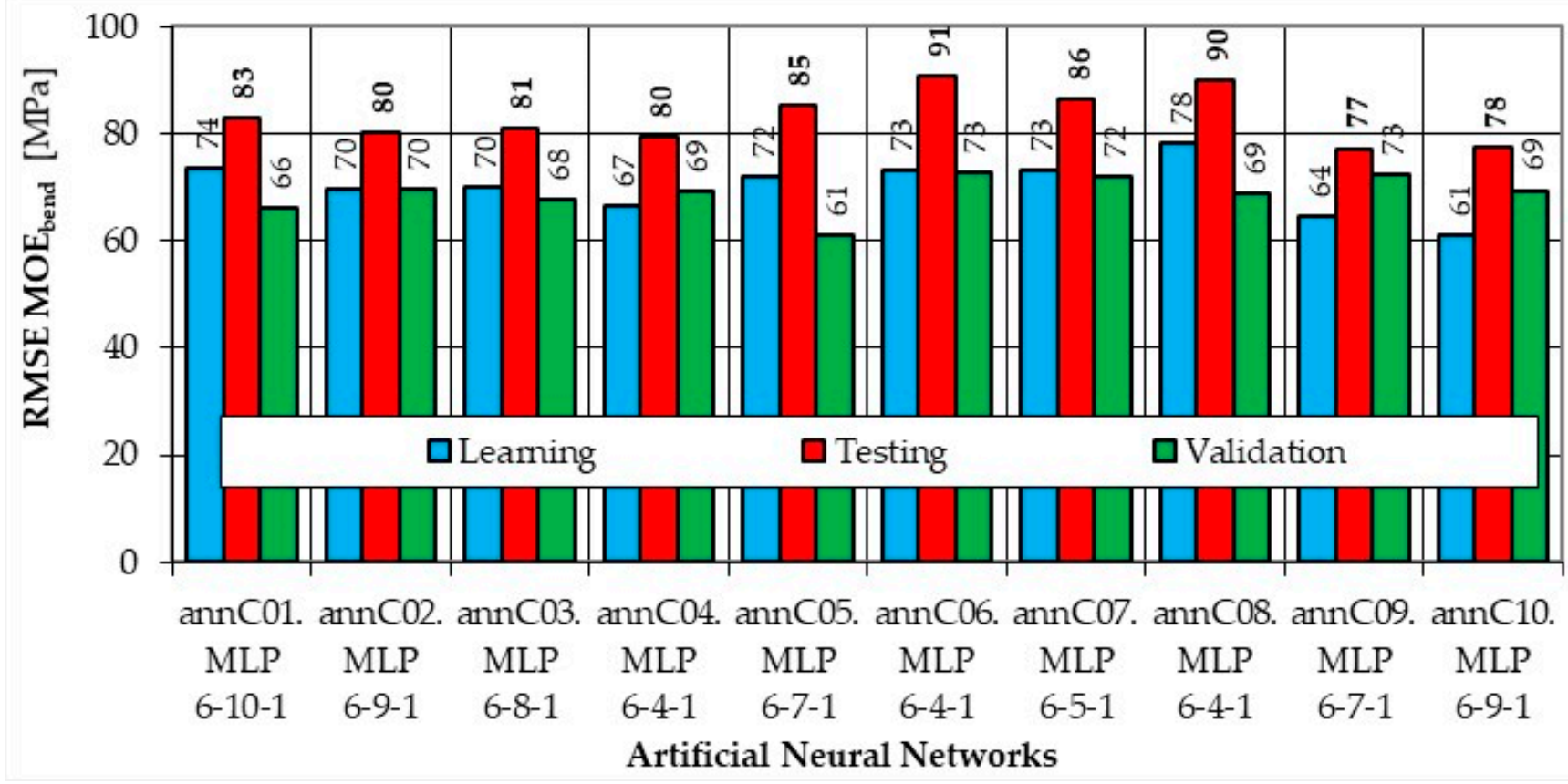

Figure A3. RMSE error values for the $\mathrm{MOE}_{\mathrm{bend}}$ dependent variable, for the semantic model C (ANN with 6 inputs) for learning, testing and validation data. 


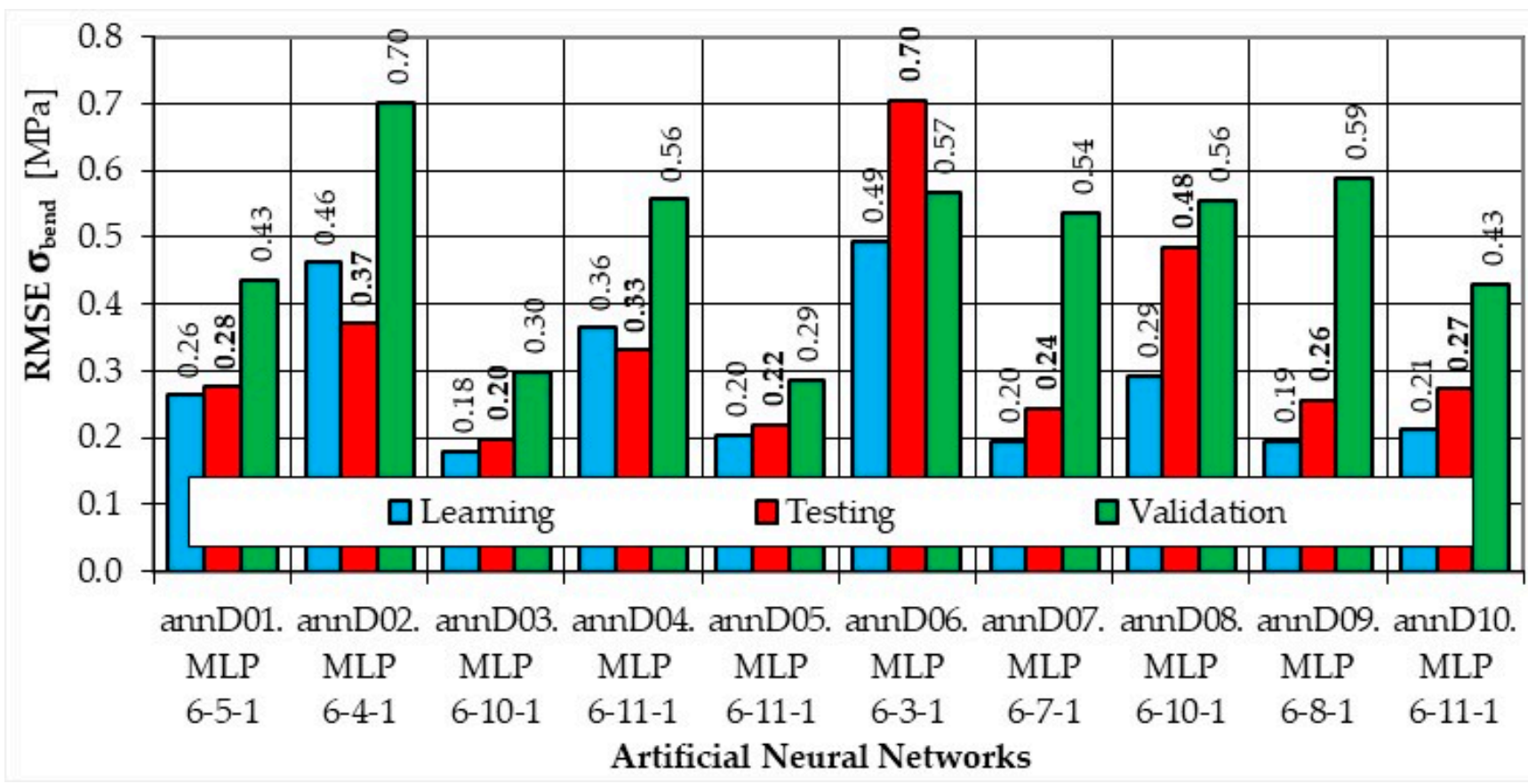

Figure A4. RMSE error values for the $\sigma_{\text {bend }}$ dependent variable, for the semantic model D (ANN with 6 inputs) for learning, testing and validation data.

Appendix B

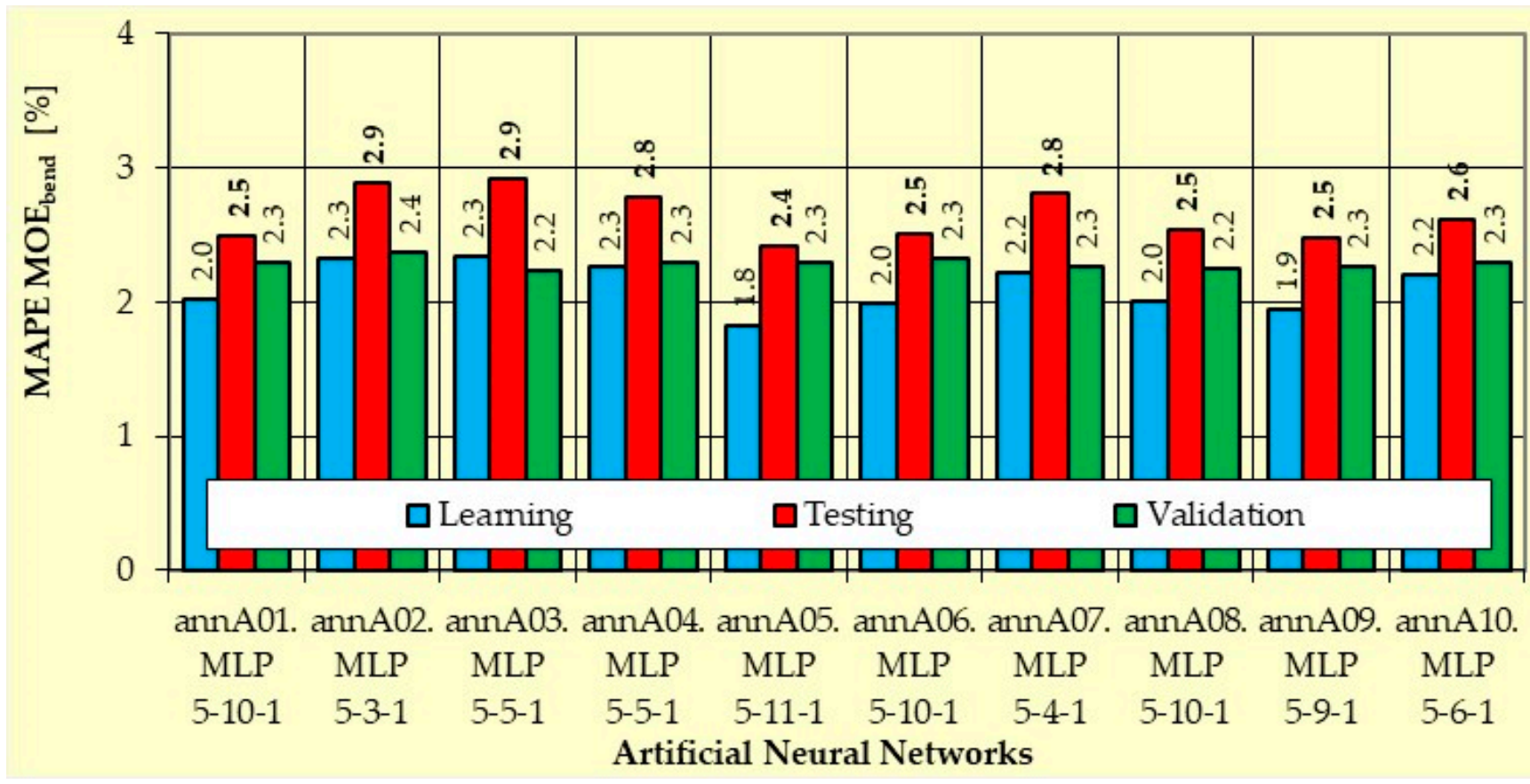

Figure A5. MAPE error values for the $\mathrm{MOE}_{\mathrm{bend}}$ dependent variable, for the semantic model A (ANN with 5 inputs) for learning, testing and validation data. 


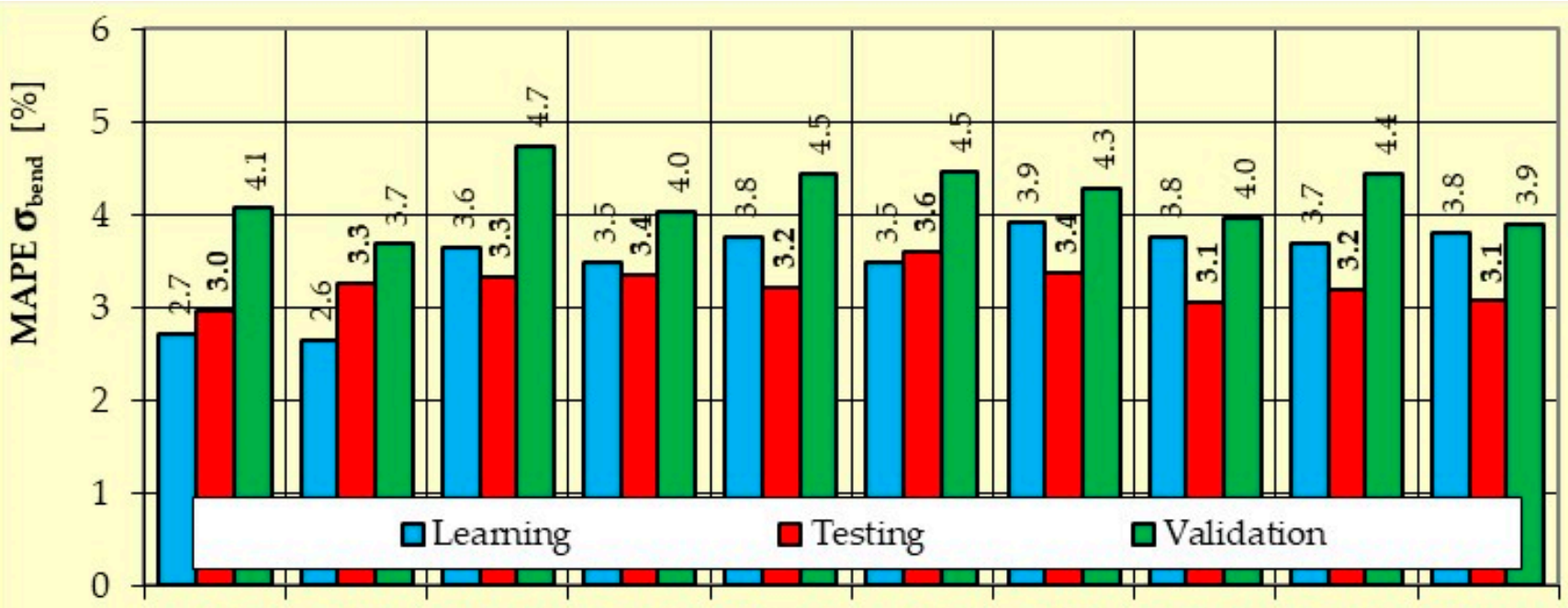

annB01. annB02. annB03. annB04. annB05. annB06. annB07. annB08. annB09. annB10.

MLP MLP MLP MLP MLP MLP MLP MLP MLP MLP

5-11-1 5-10-1 5-4-1 5-4-1 5-6-1 5-11-1 $\quad 5-8-1 \quad 5-3-1 \quad 5-4-1 \quad 5-3-1$

Artificial Neural Networks

Figure A6. MAPE error values for the $\sigma_{\text {bend }}$ dependent variable, for the semantic model B (ANN with 5 inputs) for learning, testing and validation data.

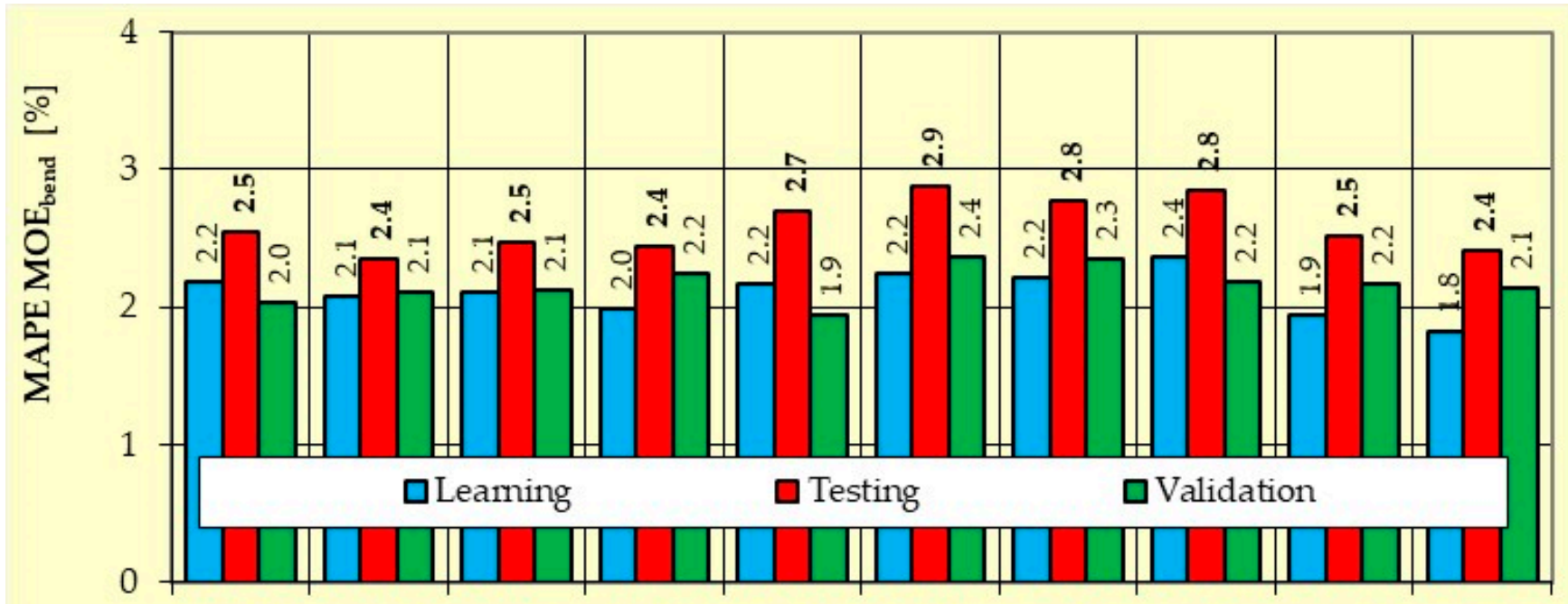

annC01. annC02. annC03. annC04. annC05. annC06. annC07. annC08. annC09. annC10.

MLP MLP MLP MLP MLP MLP MLP MLP MLP MLP 6-10-1 6-9-1 6-8-1 $\quad 6-4-1 \quad 6-7-1 \quad 6-4-1 \quad 6-5-1 \quad 6-4-1 \quad 6-7-1 \quad 6-9-1$

\section{Artificial Neural Networks}

Figure A7. MAPE error values for the $\mathrm{MOE}_{\mathrm{bend}}$ dependent variable, for the semantic model C (ANN with 6 inputs) for learning, testing and validation data. 


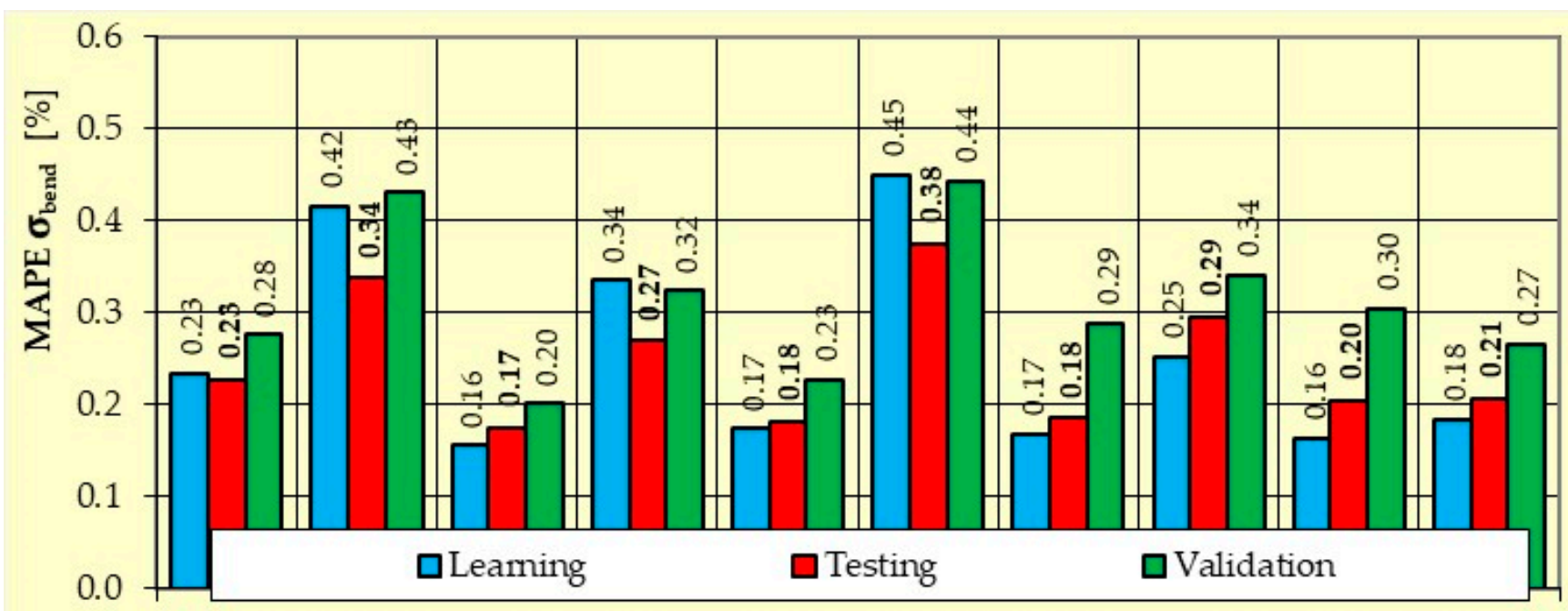

annD01. annD02. annD03. annD04. annD05. annD06. annD07. annD08. annD09. annD10.

\begin{tabular}{cccccccccc} 
MLP & MLP & MLP & MLP & MLP & MLP & MLP & MLP & MLP & MLP \\
$6-5-1$ & $6-4-1$ & $6-10-1$ & $6-11-1$ & $6-11-1$ & $6-3-1$ & $6-7-1$ & $6-10-1$ & $6-8-1$ & $6-11-1$ \\
& \multicolumn{8}{c}{ Artificial Neural Networks }
\end{tabular}

Figure A8. MAPE error values for the $\sigma_{\text {bend }}$ dependent variable, for the semantic model D (ANN with 6 inputs) for learning, testing and validation data.

Appendix C

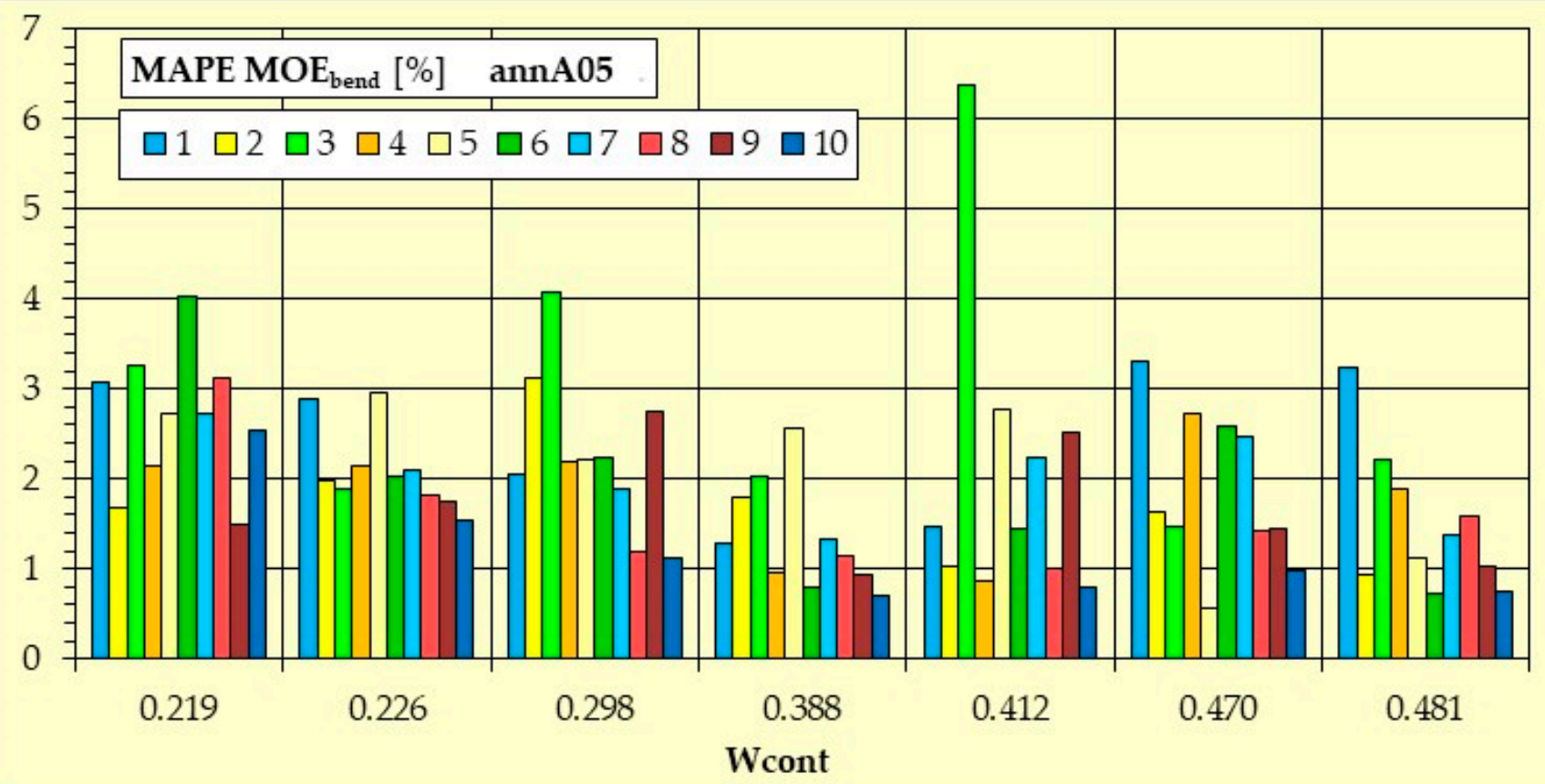

Figure A9. MAPE error values for the $\mathrm{MOE}_{\text {bend }}$ dependent variable for annA05 (MLP 5-11-1), depending on the internode number (NrNod) and water content (Wcont). Testing data: Wcont $=0.219$ $(\mathrm{NrNod}=3,6,8) ; \mathrm{Wcont}=0.226(\mathrm{NrNod}=3) ; \mathrm{Wcont}=0.388(\mathrm{NrNod}=6) ; \mathrm{Wcont}=0.412(\operatorname{NrNod}=4$, $5,7)$; Wcont $=0.470(\mathrm{NrNod}=4,7)$. Validation data: $\mathrm{Wcont}=0.219(\mathrm{NrNod}=5) ; \mathrm{Wcont}=0.226$ $(\operatorname{NrNod}=7,10) ;$ Wcont $=0.298(\operatorname{NrNod}=2,3,9) ;$ Wcont $=0.412(\operatorname{NrNod}=10) ;$ Wcont $=0.481$ $(\mathrm{NrNod}=4,7)$. The remaining values not mentioned are the learning data subset. 




Figure A10. MAPE error values for the $\sigma_{\text {bend }}$ dependent variable for annB01 (MLP 5-11-1), depending on the internode number (NrNod) and water content (Wcont). Testing data: Wcont $=0.219(\mathrm{NrNod}=3$, $6,8)$; Wcont $=0.226(\mathrm{NrNod}=3)$; Wcont $=0.388(\mathrm{NrNod}=6) ; \mathrm{Wcont}=0.412(\mathrm{NrNod}=4,5,7)$; Wcont $=0.470(\mathrm{NrNod}=4,7)$. Validation data: $\mathrm{Wcont}=0.219(\mathrm{NrNod}=5) ; \mathrm{Wcont}=0.226(\mathrm{NrNod}=7,10)$; Wcont $=0.298(\operatorname{NrNod}=2,3,9) ;$ Wcont $=0.412(\operatorname{NrNod}=10) ;$ Wcont $=0.481(\operatorname{NrNod}=4,7)$. The remaining values not mentioned are the learning data subset.

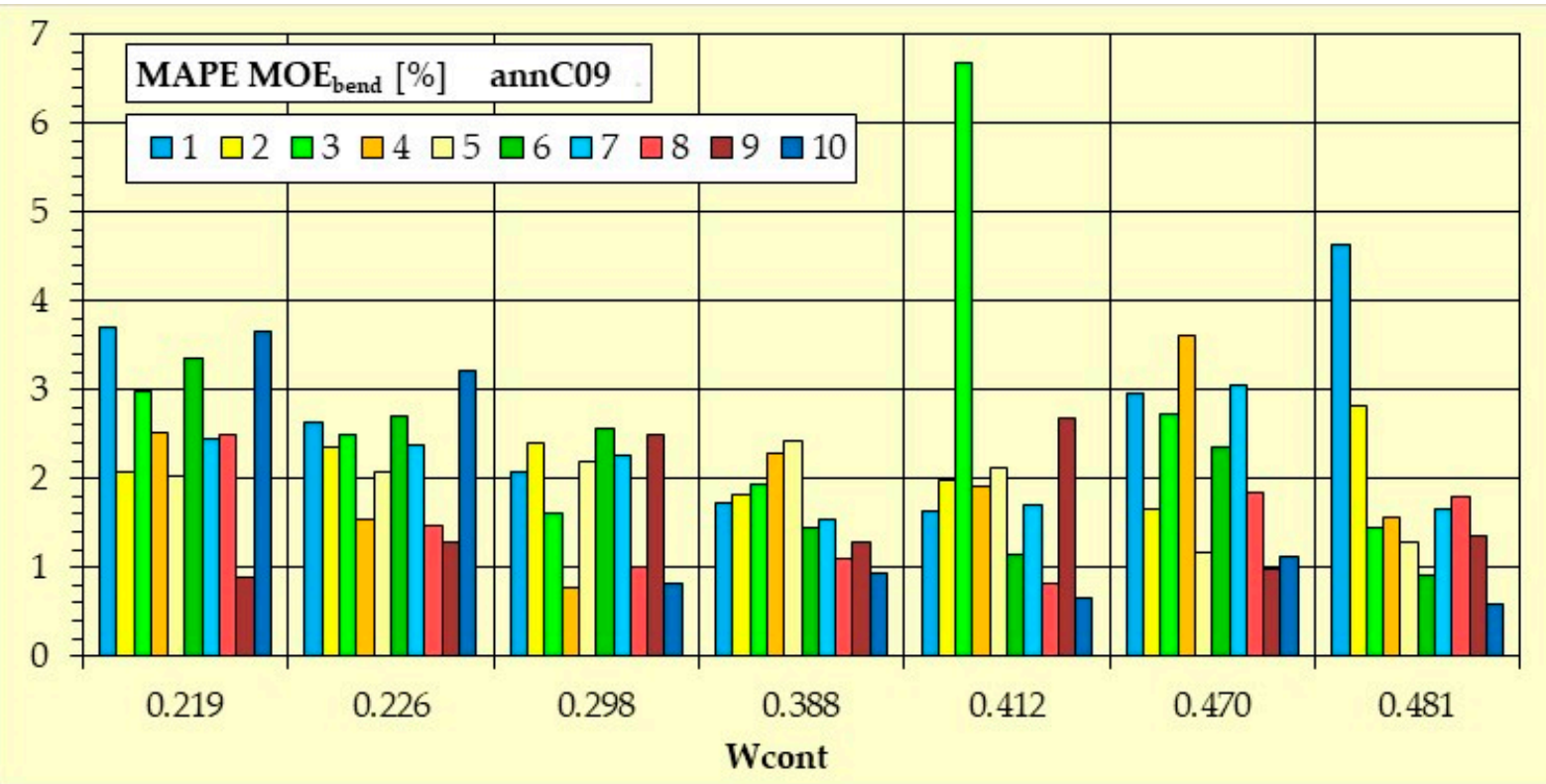

Figure A11. MAPE error values for the $\mathrm{MOE}_{\text {bend }}$ dependent variable for annC09 (MLP 6-7-1), depending on the internode number (NrNod) and water content (Wcont). Testing data: Wcont $=0.219$ $(\mathrm{NrNod}=3,6,8) ; \mathrm{Wcont}=0.226(\mathrm{NrNod}=3) ; \mathrm{Wcont}=0.388(\mathrm{NrNod}=6) ; \mathrm{Wcont}=0.412(\operatorname{NrNod}=4$, $5,7)$; Wcont $=0.470(\mathrm{NrNod}=4,7)$. Validation data: Wcont $=0.219(\mathrm{NrNod}=5) ; \mathrm{Wcont}=0.226$ $(\operatorname{NrNod}=7,10) ;$ Wcont $=0.298(\operatorname{NrNod}=2,3,9) ; \mathrm{Wcont}=0.412(\operatorname{NrNod}=10) ;$ Wcont $=0.481$ $(\mathrm{NrNod}=4,7)$. The remaining values not mentioned are the learning data subset. 


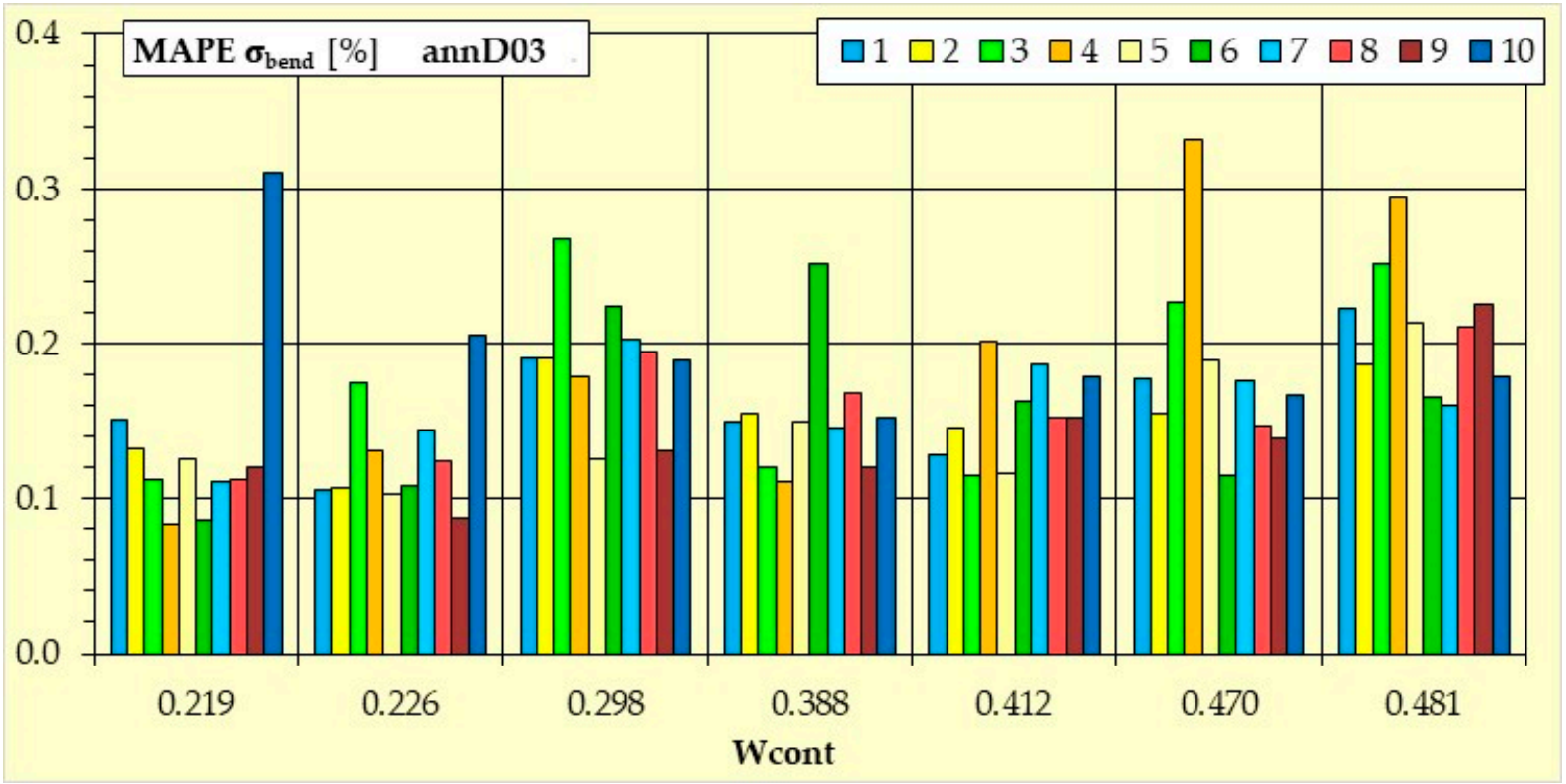

Figure A12. MAPE error values for the $\sigma_{\text {bend }}$ dependent variable for annD03 (MLP 6-10-1), depending on the internode number (NrNod) and water content (Wcont). Testing data: Wcont $=0.219(\mathrm{NrNod}=3$, 6, 8); Wcont = 0.226 (NrNod = 3); Wcont = $0.388(\mathrm{NrNod}=6)$; Wcont = $0.412(\operatorname{NrNod}=4,5,7)$; Wcont $=0.470(\operatorname{NrNod}=4,7)$. Validation data: $\mathrm{Wcont}=0.219(\mathrm{NrNod}=5) ; \mathrm{Wcont}=0.226(\operatorname{NrNod}=7,10)$; Wcont $=0.298(\operatorname{NrNod}=2,3,9) ; \mathrm{Wcont}=0.412(\operatorname{NrNod}=10) ; \mathrm{Wcont}=0.481(\mathrm{NrNod}=4,7)$. The remaining values not mentioned are the learning data subset.

Table A1. Weights and biases between the input layer and the hidden layer as well as those between the hidden layer and the output layer for the annA05 neural network.

\begin{tabular}{|c|c|c|c|c|c|}
\hline \multicolumn{3}{|c|}{$\begin{array}{l}\text { Weights and Biases between } \\
\text { Input and Hidden Layers }\end{array}$} & \multicolumn{3}{|c|}{$\begin{array}{l}\text { Weights and Biases between } \\
\text { Hidden and Output Layers }\end{array}$} \\
\hline \multicolumn{2}{|c|}{ Connections } & & \multicolumn{2}{|c|}{ Connections } & \multirow[b]{2}{*}{ Weights } \\
\hline $\begin{array}{l}\text { Input } \\
\text { Neuron }\end{array}$ & $\begin{array}{l}\text { Hidden } \\
\text { Neuron }\end{array}$ & Weights & $\begin{array}{l}\text { Hidden } \\
\text { Neuron }\end{array}$ & $\begin{array}{l}\text { Output } \\
\text { Neuron }\end{array}$ & \\
\hline Wcont & \multirow{6}{*}{1} & -1.9046 & \multirow{6}{*}{1} & \multirow{6}{*}{$\mathrm{MOE}_{\text {bend }}$} & \multirow{6}{*}{-2.0160} \\
\hline NrNod & & 2.4885 & & & \\
\hline $\mathrm{D}_{\text {steam Max }}$ & & -2.7905 & & & \\
\hline $\mathrm{D}_{\text {stem min }}$ & & 3.1284 & & & \\
\hline $\mathrm{Th}_{\text {steam }}$ & & 3.6997 & & & \\
\hline Bias & & -4.6094 & & & \\
\hline Wcont & \multirow{6}{*}{2} & 1.7757 & \multirow{6}{*}{2} & \multirow{6}{*}{$\mathrm{MOE}_{\text {bend }}$} & \multirow{6}{*}{-0.3861} \\
\hline NrNod & & -10.4613 & & & \\
\hline $\mathrm{D}_{\text {steam Max }}$ & & 3.1509 & & & \\
\hline $\mathrm{D}_{\text {stem min }}$ & & 2.6889 & & & \\
\hline $\mathrm{Th}_{\text {steam }}$ & & 6.5689 & & & \\
\hline Bias & & 3.5696 & & & \\
\hline Wcont & \multirow{6}{*}{3} & -2.7473 & \multirow{6}{*}{3} & \multirow{6}{*}{$\mathrm{MOE}_{\text {bend }}$} & \multirow{6}{*}{-0.1412} \\
\hline NrNod & & -9.5350 & & & \\
\hline $\mathrm{D}_{\text {steam Max }}$ & & 3.8914 & & & \\
\hline $\mathrm{D}_{\text {stem min }}$ & & -1.6132 & & & \\
\hline $\mathrm{Th}_{\text {steam }}$ & & 9.4627 & & & \\
\hline Bias & & 2.6229 & & & \\
\hline
\end{tabular}


Table A1. Cont.

\begin{tabular}{|c|c|c|c|c|c|}
\hline \multicolumn{3}{|c|}{$\begin{array}{l}\text { Weights and Biases between } \\
\text { Input and Hidden Layers }\end{array}$} & \multicolumn{3}{|c|}{$\begin{array}{l}\text { Weights and Biases between } \\
\text { Hidden and Output Layers }\end{array}$} \\
\hline \multicolumn{2}{|c|}{ Connections } & \multirow[b]{2}{*}{ Weights } & \multicolumn{2}{|c|}{ Connections } & \multirow[b]{2}{*}{ Weights } \\
\hline $\begin{array}{l}\text { Input } \\
\text { Neuron }\end{array}$ & $\begin{array}{l}\text { Hidden } \\
\text { Neuron }\end{array}$ & & $\begin{array}{l}\text { Hidden } \\
\text { Neuron }\end{array}$ & $\begin{array}{l}\text { Output } \\
\text { Neuron }\end{array}$ & \\
\hline Wcont & \multirow{6}{*}{4} & 3.0543 & \multirow{6}{*}{4} & \multirow{6}{*}{$\mathrm{MOE}_{\text {bend }}$} & \multirow{6}{*}{-1.2546} \\
\hline NrNod & & -12.4148 & & & \\
\hline $\mathrm{D}_{\text {steam Max }}$ & & 2.8839 & & & \\
\hline $\mathrm{D}_{\text {stem min }}$ & & 1.8528 & & & \\
\hline Th & & 1.6986 & & & \\
\hline Bias & & -3.9850 & & & \\
\hline Wcont & \multirow{6}{*}{5} & -2.9733 & \multirow{6}{*}{5} & \multirow{6}{*}{$\mathrm{MOE}_{\text {bend }}$} & \multirow{6}{*}{9.3524} \\
\hline NrNod & & -12.8446 & & & \\
\hline $\mathrm{D}_{\text {steam Max }}$ & & -4.5719 & & & \\
\hline $\mathrm{D}_{\text {stem min }}$ & & 3.5891 & & & \\
\hline $\mathrm{Th}_{\text {steam }}$ & & 3.6138 & & & \\
\hline Bias & & -5.1506 & & & \\
\hline Wcont & \multirow{6}{*}{6} & 1.7490 & \multirow{6}{*}{6} & \multirow{6}{*}{$\mathrm{MOE}_{\mathrm{bend}}$} & \multirow{6}{*}{0.3699} \\
\hline NrNod & & -4.3593 & & & \\
\hline $\mathrm{D}_{\text {steam Max }}$ & & 2.5651 & & & \\
\hline $\mathrm{D}_{\text {stem min }}$ & & 3.7031 & & & \\
\hline $\mathrm{Th}_{\text {steam }}$ & & 4.6927 & & & \\
\hline Bias & & -0.8075 & & & \\
\hline Wcont & \multirow{6}{*}{7} & -2.8369 & \multirow{6}{*}{7} & & \\
\hline NrNod & & 1.9192 & & & \\
\hline $\mathrm{D}_{\text {steam Max }}$ & & 0.7166 & & & \\
\hline $\mathrm{D}_{\text {stem min }}$ & & 1.3162 & & $\mathrm{MOE}_{\mathrm{bend}}$ & -2.1642 \\
\hline $\mathrm{Th}_{\text {steam }}$ & & 2.5379 & & & \\
\hline Bias & & -5.0349 & & & \\
\hline Wcont & & 0.7975 & & & \\
\hline NrNod & & -8.7901 & & & \\
\hline $\mathrm{D}_{\text {steam Max }}$ & & 0.6474 & & & \\
\hline $\mathrm{D}_{\text {stem min }}$ & 8 & 6.1603 & 8 & $\mathrm{MUE}$ bend & -8.6974 \\
\hline $\mathrm{Th}_{\text {steam }}$ & & 3.5364 & & & \\
\hline Bias & & -11.3223 & & & \\
\hline Wcont & & 6.3097 & & & \\
\hline NrNod & & -0.9085 & & & \\
\hline $\mathrm{D}_{\text {steam Max }}$ & 9 & 4.1519 & o & & \\
\hline $\mathrm{D}_{\text {stem min }}$ & 9 & 0.0516 & 9 & $\mathrm{M} U \mathrm{E}_{\text {bend }}$ & -2.8854 \\
\hline $\mathrm{Th}_{\text {steam }}$ & & -4.4881 & & & \\
\hline Bias & & 3.2790 & & & \\
\hline Wcont & & 2.6881 & & & \\
\hline NrNod & & -8.4866 & & & \\
\hline$D_{\text {steam Max }}$ & 10 & 1.7032 & 10 & $\mathrm{MOF}_{1}$ & 23047 \\
\hline $\mathrm{D}_{\text {stem min }}$ & 10 & 0.7164 & 10 & MUE End & 2.3047 \\
\hline $\mathrm{Th}_{\text {steam }}$ & & -1.2511 & & & \\
\hline Bias & & -2.2674 & & & \\
\hline Wcont & & 1.3527 & & & \\
\hline NrNod & & 0.3887 & & & \\
\hline $\mathrm{D}_{\text {steam Max }}$ & & 5.3995 & & & \\
\hline $\mathrm{D}_{\text {stem min }}$ & 11 & 0.9965 & 11 & $\mathrm{MOE}_{\text {bend }}$ & -0.5312 \\
\hline $\mathrm{Th}_{\text {steam }}$ & & -3.0340 & & & \\
\hline Bias & & -2.9259 & & & \\
\hline- & - & - & Bias & $\mathrm{MOE}_{\text {bend }}$ & 2.9477 \\
\hline
\end{tabular}


Table A2. Weights and biases between the input layer and the hidden layer as well as those between the hidden layer and the output layer for the annD03 neural network.

\begin{tabular}{|c|c|c|c|c|c|}
\hline \multicolumn{3}{|c|}{$\begin{array}{l}\text { Weights and Biases between } \\
\text { Input and Hidden Layers }\end{array}$} & \multicolumn{3}{|c|}{$\begin{array}{l}\text { Weights and Biases between } \\
\text { Hidden and Output Layers }\end{array}$} \\
\hline \multicolumn{2}{|c|}{ Connections } & & \multicolumn{2}{|c|}{ Connections } & \multirow[b]{2}{*}{ Weights } \\
\hline $\begin{array}{l}\text { Input } \\
\text { Neuron }\end{array}$ & $\begin{array}{l}\text { Hidden } \\
\text { Neuron }\end{array}$ & Weights & $\begin{array}{l}\text { Hidden } \\
\text { Neuron }\end{array}$ & $\begin{array}{l}\text { Output } \\
\text { Neuron }\end{array}$ & \\
\hline Wcont & \multirow{7}{*}{1} & 0.46161 & \multirow{7}{*}{1} & \multirow{7}{*}{$\sigma_{\text {bend }}$} & \multirow{7}{*}{1.52045} \\
\hline NrNod & & -0.03784 & & & \\
\hline $\mathrm{D}_{\text {steam Max }}$ & & -0.60342 & & & \\
\hline $\mathrm{D}_{\text {stem min }}$ & & -2.48068 & & & \\
\hline $\mathrm{Th}_{\text {steam }}$ & & -1.42360 & & & \\
\hline $\mathrm{F}_{\text {bend Max }}$ & & 1.11253 & & & \\
\hline Bias & & -1.53380 & & & \\
\hline Wcont & \multirow{7}{*}{2} & 0.90075 & \multirow{7}{*}{2} & \multirow{7}{*}{$\sigma_{\text {bend }}$} & \multirow{7}{*}{0.65696} \\
\hline NrNod & & -0.34368 & & & \\
\hline $\mathrm{D}_{\text {steam Max }}$ & & 0.30125 & & & \\
\hline $\mathrm{D}_{\text {stem min }}$ & & 0.99976 & & & \\
\hline $\mathrm{Th}_{\text {steam }}$ & & -0.25100 & & & \\
\hline$F_{\text {bend Max }}$ & & 1.38583 & & & \\
\hline Bias & & 0.64301 & & & \\
\hline Wcont & \multirow{7}{*}{3} & 0.11674 & \multirow{7}{*}{3} & \multirow{7}{*}{$\sigma_{\text {bend }}$} & \multirow{7}{*}{-2.56040} \\
\hline NrNod & & 0.07561 & & & \\
\hline $\mathrm{D}_{\text {steam Max }}$ & & -0.10368 & & & \\
\hline $\mathrm{D}_{\text {stem min }}$ & & -0.30686 & & & \\
\hline $\mathrm{Th}_{\text {steam }}$ & & 0.09658 & & & \\
\hline $\mathrm{F}_{\text {bend Max }}$ & & -0.84279 & & & \\
\hline Bias & & -0.83605 & & & \\
\hline Wcont & \multirow{7}{*}{4} & 0.13237 & \multirow{7}{*}{4} & \multirow{7}{*}{$\sigma_{\text {bend }}$} & \\
\hline NrNod & & -0.32838 & & & \\
\hline $\mathrm{D}_{\text {steam Max }}$ & & -0.52042 & & & \\
\hline $\mathrm{D}_{\text {stem min }}$ & & -1.88645 & & & -3.48714 \\
\hline $\mathrm{Th}_{\text {steam }}$ & & -1.19246 & & & \\
\hline $\mathrm{F}_{\text {bend Max }}$ & & -3.61781 & & & \\
\hline Bias & & -1.60437 & & & \\
\hline Wcont & & 0.07777 & & & \\
\hline NrNod & & 0.21921 & & & \\
\hline $\mathrm{D}_{\text {steam Max }}$ & & -0.30698 & & & \\
\hline $\mathrm{D}_{\text {stem min }}$ & 5 & -0.54980 & 5 & $\sigma_{\text {bend }}$ & 1.87011 \\
\hline $\mathrm{Th}_{\text {steam }}$ & & 0.01191 & & & \\
\hline $\mathrm{F}_{\text {bend Max }}$ & & -0.10285 & & & \\
\hline Bias & & 0.50076 & & & \\
\hline Wcont & & -0.08613 & & & \\
\hline NrNod & & 0.30877 & & & \\
\hline $\mathrm{D}_{\text {steam Max }}$ & & 0.06363 & & & \\
\hline $\mathrm{D}_{\text {stem min }}$ & 6 & 0.35557 & 6 & $\sigma_{\text {bend }}$ & -1.25730 \\
\hline $\mathrm{Th}_{\text {steam }}$ & & -0.08044 & & & \\
\hline $\mathrm{F}_{\text {bend Max }}$ & & -0.14423 & & & \\
\hline Bias & & -0.38527 & & & \\
\hline Wcont & & -0.10644 & & & \\
\hline NrNod & & -0.10213 & & & \\
\hline DsteamMax & & -1.39496 & & & \\
\hline Dstemmin & 7 & -1.47598 & 7 & $\sigma_{\text {bend }}$ & 4.13679 \\
\hline Thsteam & & -5.34947 & & & \\
\hline $\mathrm{F}_{\text {bend Max }}$ & & 3.03086 & & & \\
\hline Bias & & -2.17910 & & & \\
\hline
\end{tabular}


Table A2. Cont.



\section{References}

1. Karbowniczak, A.; Hamerska, J.; Wrobel, M.; Jewiarz, M.; Necka, K. Evaluation of Selected Species of Woody Plants in Terms of Suitability for Energy Production. In Proceedings of the Renewable Energy Sources: Engineering, Technology, Innovation; Mudryk, K., Werle, S., Eds.; Springer International Publishing AG: Cham, Switzerland, 2018; pp. 735-742.

2. Dyjakon, A.; Sobol, Ł.; Krotowski, M.; Mudryk, K.; Kawa, K. The impact of particles comminution on mechanical durability of wheat straw briquettes. Energies 2020, 13, 6186. [CrossRef]

3. Wrobel, M.; Jewiarz, M.; Mudryk, K.; Knapczyk, A. Influence of Raw Material Drying Temperature on the Scots Pine (Pinus sylvestris L.) Biomass Agglomeration Process-A Preliminary Study. Energies 2020, 13, 1809. [CrossRef]

4. Niemczyk, M.; Bachilava, M.; Wróbel, M.; Jewiarz, M.; Kavtaradze, G.; Goginashvili, N. Productivity and biomass properties of poplar clones managed in short-rotation culture as a potential fuelwood source in georgia. Energies 2021, 14, 3016. [CrossRef]

5. Wrobel, M.; Mudryk, K.; Jewiarz, M.; Glowacki, S.; Tulej, W. Characterization of Selected Plant Species in Terms of Energetic Use. In Renewable Energy Sources: Engineering, Technology, Innovation; Mudryk, K., Werle, S., Eds.; Springer International Publishing AG: Cham, Switzerland, 2018; pp. 671-681. ISBN 978-3-319-72371-6/978-3-319-72370-9.

6. Dołzyńska, M.; Obidziński, S.; Kowczyk-Sadowy, M.; Krasowska, M. Densification and combustion of cherry stones. Energies 2019, 12, 3042. [CrossRef]

7. García, R.; Gil, M.V.; Rubiera, F.; Pevida, C. Pelletization of wood and alternative residual biomass blends for producing industrial quality pellets. Fuel 2019, 251, 739-753. [CrossRef]

8. Bryś, A.; Zielińska, J.; Głowacki, S.; Tulej, W.; Bryś, J. Analysis of possibilities of using biomass from cherry and morello cherry stones for energy purposes. In Proceedings of the E3S Web of Conferences; EDP Sciences: Ulys, France, 2020; Volume 154.

9. Mudryk, K.; Jewiarz, M.; Wróbel, M.; Niemiec, M.; Dyjakon, A. Evaluation of urban tree leaf biomass-potential, physicomechanical and chemical parameters of raw material and solid biofuel. Energies 2021, 14, 818. [CrossRef]

10. Rezania, S.; Ponraj, M.; Din, M.F.M.; Songip, A.R.; Sairan, F.M.; Chelliapan, S. The diverse applications of water hyacinth with main focus on sustainable energy and production for new era: An overview. Renew. Sustain. Energy Rev. 2015, 41, 943-954. [CrossRef]

11. Brzychczyk, B.; Hebda, T.; Pedryc, N. The influence of artificial lighting systems on the cultivation of algae: The example of chlorella vulgaris. Energies 2020, 13, 5994. [CrossRef] 
12. Clifton-Brown, J.C.; Lewandowski, I.; Andersson, B.; Basch, G.; Christian, D.G.; Kjeldsen, J.B.; Jørgensen, U.; Mortensen, J.V.; Riche, A.B.; Schwarz, K.-U.; et al. Performance of 15 Miscanthus genotypes at five sites in Europe. Agron. J. 2001, 93, 1013-1019. [CrossRef]

13. Chae, W.B.; Hong, S.J.; Gifford, J.M.; Lane Rayburn, A.; Widholm, J.M.; Juvik, J.A. Synthetic polyploid production of miscanthus sacchariflorus, miscanthus sinensis, and miscanthus x giganteus. GCB Bioenergy 2013, 5, 338-350. [CrossRef]

14. Doczekalska, B.; Bartkowiak, M.; Waliszewska, B.; Orszulak, G.; Cerazy-Waliszewska, J.; Pniewski, T. Characterization of Chemically Activated Carbons Prepared from Miscanthus and Switchgrass Biomass. Materials 2020, 13, 1654. [CrossRef] [PubMed]

15. Pointeau, S.; Jaguenet, E.; Couty, A.; Dubois, F.; Rambaud, C.; Ameline, A. Differential performance and behavior of the corn leaf aphid, Rhopalosiphum maidis, on three species of the biomass crop miscanthus. Ind. Crops Prod. 2014, 54, 135-141. [CrossRef]

16. Francik, S.; Knapczyk, A.; Knapczyk, A.; Francik, R. Decision Support System for the Production of Miscanthus and Willow Briquettes. Energies 2020, 13, 1364. [CrossRef]

17. Styks, J.; Wróbel, M.; Fraczek, J.; Knapczyk, A. Effect of compaction pressure and moisture content on quality parameters of perennial biomass pellets. Energies 2020, 13, 1859. [CrossRef]

18. Fusi, A.; Bacenetti, J.; Proto, A.R.; Tedesco, D.E.A.; Pessina, D.; Facchinetti, D. Pellet Production from Miscanthus: Energy and Environmental Assessment. Energies 2021, 14, 73. [CrossRef]

19. Jach-Nocon, M.; Pełka, G.; Luboń, W.; Mirowski, T.; Nocoń, A.; Pachytel, P. An Assessment of the Efficiency and Emissions of a Pellet Boiler Combusting Multiple Pellet Types. Energies 2021, 14, 4465. [CrossRef]

20. Hodgson, E.M.; Nowakowski, D.J.; Shield, I.; Riche, A.; Bridgwater, A.V.; Clifton-Brown, J.C.; Donnison, I.S. Variation in Miscanthus chemical composition and implications for conversion by pyrolysis and thermo-chemical bio-refining for fuels and chemicals. Bioresour. Technol. 2011, 102, 3411-3418. [CrossRef]

21. Kiesel, A.; Wagner, M.; Lewandowski, I. Environmental Performance of Miscanthus, Switchgrass and Maize: Can C4 Perennials Increase the Sustainability of Biogas Production? Sustainability 2017, 9, 5. [CrossRef]

22. Smuga-Kogut, M.; Kogut, T.; Markiewicz, R.; Słowik, A. Use of Machine Learning Methods for Predicting Amount of Bioethanol Obtained from Lignocellulosic Biomass with the Use of Ionic Liquids for Pretreatment. Energies 2021, 14, 243. [CrossRef]

23. Marín, F.; Sánchez, J.L.; Arauzo, J.; Fuertes, R.; Gonzalo, A. Semichemical pulping of Miscanthus giganteus. Effect of pulping conditions on some pulp and paper properties. Bioresour. Technol. 2009, 100, 3933-3940. [CrossRef]

24. Dias, P.P.; Waldmann, D. Optimisation of the mechanical properties of Miscanthus lightweight concrete. Constr. Build. Mater. 2020, 258, 119643. [CrossRef]

25. Voicu, G.; Moiceanu, E.; Sandu, M.; Poenaru, I.C.; Voicu, P. Experiments regarding mechanical behaviour of energetic plant miscanthus to crushing and shear stress. In Proceedings of the Engineering for Rural Development, Jelgava, Latvia, 26-27 May 2011; pp. 490-495.

26. Johnson, P.C.; Clementson, C.L.; Mathanker, S.K.; Grift, T.E.; Hansen, A.C. Cutting energy characteristics of Miscanthus $\times$ giganteus stems with varying oblique angle and cutting speed. Biosyst. Eng. 2012, 112, 42-48. [CrossRef]

27. Liu, Q.; Mathanker, S.K.; Zhang, Q.; Hansen, A.C. Biomechanical properties of miscanthus stems. Trans. ASABE 2012, 55, 1125-1131. [CrossRef]

28. Boydaş, M.G.; Çomakli, M.; Sayinci, B.; Kara, M. Effects of moisture content, internode region, and oblique angle on the mechanical properties of sainfoin stem. Turkish J. Agric. For. 2019, 43, 254-263. [CrossRef]

29. Słupska, M.; Dyjakon, A.; Stopa, R. Determination of strength properties of energy plants on the example of miscanthus-giganteus, rosa multiflora and salix viminalis. Energies 2019, 12, 3660. [CrossRef]

30. Wójcik, A.; Frączek, J.; Niemczewska-Wójcik, M. The relationship between static and kinetic friction for plant granular materials. Powder Technol. 2020, 361, 739-747. [CrossRef]

31. Wójcik, A.; Frączek, J.; Wota, A.K. The methodical aspects of the friction modeling of plant granular materials. Powder Technol. 2019, 344, 504-513. [CrossRef]

32. Lubis, A.; Mandang, T.; Hermawan, W. Sutrisno Study of the physical and mechanical characteristics of patchouli plants. AIMS Agric. Food 2021, 6, 525-537. [CrossRef]

33. Gomez, F.E.; Muliana, A.H.; Rooney, W.L. Predicting stem strength in diverse bioenergy sorghum genotypes. Crop Sci. 2018, 58, 739-751. [CrossRef]

34. Kaack, K.; Schwarz, K.-U. Morphological and mechanical properties of Miscanthus in relation to harvesting, lodging, and growth conditions. Ind. Crops Prod. 2001, 14, 145-154. [CrossRef]

35. Kaack, K.; Schwarz, K.-U.; Brander, P.E. Variation in morphology, anatomy and chemistry of stems of Miscanthus genotypes differing in mechanical properties. Ind. Crops Prod. 2003, 17, 131-142. [CrossRef]

36. Zhen, C.; Xin, J.; Qingxi, L. Experimental research on physical and mechanical parameters of matured bottom stalk of the reed. Int. J. Agric. Biol. Eng. 2011, 4, 36-42. [CrossRef]

37. Moiceanu, G.; Voicu, G.; Paraschiv, G.; Poenaru, I.C.; Pirnă, I. Some physical-biological characteristics of miscanthus energetic plant stalks [Unele caracteristici fizico-biologice ale tulpinilor plantei energetice miscanthus]. INMATEH-Agric. Eng. 2012, 38, 53-58.

38. Jiménez-Espada, M.; Herrero-Adán, D.; González-Escobar, R. Characterization of Mechanical and Hygroscopic Properties of Individual Canes of Reed. Materials 2021, 14, 2193. [CrossRef] 
39. Kasantikul, K.; Yang, D.; Wang, Q.; Lwin, A. A Novel Wind Speed Estimation Based on the Integration of an Artificial Neural Network and a Particle Filter Using BeiDou GEO Reflectometry. Sensors 2018, 18, 3350. [CrossRef]

40. Liakos, K.G.; Busato, P.; Moshou, D.; Pearson, S.; Bochtis, D.D. Machine Learning in Agriculture: A Review. Sensors 2018, 18, 2674. [CrossRef]

41. Tamouridou, A.A.; Pantazi, E.X.; Alexandridis, T.; Lagopodi, A.; Kontouris, G.; Moshou, D. Spectral Identification of Disease in Weeds Using Multilayer Perceptron with Automatic Relevance Determination. Sensors 2018, 18, 2770. [CrossRef]

42. Vlontzos, G.; Pardalos, P.M. Assess and prognosticate green house gas emissions from agricultural production of EU countries, by implementing, DEA Window analysis and artificial neural networks. Renew. Sustain. Energy Rev. 2017, 76, 155-162. [CrossRef]

43. Wrobel, M.; Fraczek, J.; Francik, S.; Slipek, Z.; Mudryk, K. Modelling of unit contact surface of bean seeds using Artificial Neural Networks. In Proceedings of the Engineering for Rural Development, Jelgava, Latvia, 23-24 May 2013; pp. $287-291$.

44. Mudryk, K.; Francik, S.; Fraczek, J.; Slipek, Z.; Wrobel, M. Model of actual contact area of rye and wheat grains with flat surface. In Proceedings of the Engineering for Rural Development, Jelgava, Latvia, 23-24 May 2013; pp. 292-296.

45. Francik, S.; Łapczyńska-Kordon, B.; Francik, R.; Wójcik, A. Modeling and Simulation of Biomass Drying Using Artificial Neural Networks. In Renewable Energy Sources: Engineering, Technology, Innovation.; Mudryk, K., Werle, S., Eds.; Springer International Publishing AG: Cham, Switzerland, 2018; pp. 571-581. ISBN 978-3-319-72371-6/978-3-319-72370-9.

46. Roshani, M.; Sattari, M.A.; Muhammad Ali, P.J.; Roshani, G.H.; Nazemi, B.; Corniani, E.; Nazemi, E. Application of GMDH neural network technique to improve measuring precision of a simplified photon attenuation based two-phase flowmeter. Flow Meas. Instrum. 2020, 75, 101804. [CrossRef]

47. Sanaat, A.; Zaidi, H. Depth of interaction estimation in a preclinical PET scanner equipped with monolithic crystals coupled to SiPMs using a deep neural network. Appl. Sci. 2020, 10, 4753. [CrossRef]

48. Tamouridou, A.A.; Alexandridis, T.K.; Pantazi, X.E.; Lagopodi, A.L.; Kashefi, J.; Kasampalis, D.; Kontouris, G.; Moshou, D. Application of Multilayer Perceptron with Automatic Relevance Determination on Weed Mapping Using. Sensors 2017, $17,2307$. [CrossRef]

49. Francik, S.; Kurpaska, S. The use of artificial neural networks for forecasting of air temperature inside a heated foil tunnel. Sensors 2020, 20, 652. [CrossRef]

50. Trajer, J.; Winiczenko, R.; Dróżdż, B. Analysis of water consumption in fruit and vegetable processing plants with the use of artificial intelligence. Appl. Sci. 2021, 11, 167. [CrossRef]

51. Pilarska, A.A.; Boniecki, P.; Idzior-Haufa, M.; Zaborowicz, M.; Pilarski, K.; Przybylak, A.; Piekarska-Boniecka, H. Image analysis methods in classifying selected malting barley varieties by neural modelling. Agriculture 2021, 11, 732. [CrossRef]

52. Krajewska-Śpiewak, J.; Lasota, I.; Kozub, B. Application of classification neural networks for identification of damage stages of degraded low alloy steel based on acoustic emission data analysis. Arch. Civ. Mech. Eng. 2020, 20, 109. [CrossRef]

53. Szwedziak, K.; Polańczyk, E.; Grzywacz, Z.; Niedbała, G.; Wojtkiewicz, W. Neural modeling of the distribution of protein, water and gluten in wheat grains during storage. Sustainability 2020, 12, 5050. [CrossRef]

54. Nisar, K.; Sabir, Z.; Zahoor Raja, M.A.; Ag Ibrahim, A.A.; Rodrigues, J.J.P.C.; Refahy Mahmoud, S.; Chowdhry, B.S.; Gupta, M. Artificial neural networks to solve the singular model with neumann-robin, dirichlet and neumann boundary conditions. Sensors 2021, 21, 6498. [CrossRef]

55. Huang, A.; Chang, F.-J. Using a self-organizing map to explore local weather features for smart urban agriculture in Northern Taiwan. Water 2021, 13, 3457. [CrossRef]

56. Bersani, C.; Ouammi, A.; Sacile, R.; Zero, E. Model predictive control of smart greenhouses as the path towards near zero energy consumption. Energies 2020, 13, 3647. [CrossRef]

57. Tina, G.M. Special Issue on Applications of Artificial Neural Networks for Energy Systems. Appl. Sci. 2019, 9, 3734. [CrossRef]

58. Sampaio, G.S.; de Aguiar Vallim Filho, A.R.; da Silva, L.S.; da Silva, L.A. Prediction of Motor Failure Time Using An Artificial Neural Network. Sensors 2019, 19, 4342. [CrossRef] [PubMed]

59. Zhou, J.; Xu, X.; Huo, X.; Li, Y. Forecasting Models for Wind Power Using Extreme-Point Symmetric Mode Decomposition and Artificial Neural Networks. Sustainability 2019, 11, 650. [CrossRef]

60. Liu, Y.; Zhang, S.; Chen, X.; Wang, J. Artificial Combined Model Based on Hybrid Nonlinear Neural Network Models and Statistics Linear Models-Research and Application for Wind Speed Forecasting. Sustainability 2018, 10, 4601. [CrossRef]

61. Bermejo, J.F.; Fernandez, J.F.G.; Polo, F.O.; Marquez, A.C. A Review of the Use of Artificial Neural Network Models for Energy and Reliability Prediction. A Study of the Solar PV, Hydraulic and Wind Energy Sources. Appl. Sci. 2019, 9, 1844. [CrossRef]

62. Tanuska, P.; Spendla, L.; Kebisek, M.; Duris, R.; Stremy, M. Smart anomaly detection and prediction for assembly process maintenance in compliance with industry 4.0. Sensors 2021, 21, 2376. [CrossRef] [PubMed]

63. Twardowski, P.; Wiciak-Pikuła, M. Prediction of Tool Wear Using Artificial Neural Networks during Turning of Hardened Steel. Materials 2019, 12, 3091. [CrossRef] [PubMed]

64. Almonti, D.; Baiocco, G.; Tagliaferri, V.; Ucciardello, N. Artificial Neural Network in Fibres Length Prediction for High Precision Control of Cellulose Refining. Materials 2019, 12, 3730. [CrossRef]

65. Lechowicz, Z.; Fukue, M.; Rabarijoely, S.; Sulewska, M.J. Evaluation of the Undrained Shear Strength of Organic Soils from a Dilatometer Test Using Artificial Neural Networks. Appl. Sci. 2018, 8, 1395. [CrossRef] 
66. Martinez-Martinez, V.; Baladron, C.; Gomez-Gil, J.; Ruiz-Ruiz, G.; Navas-Garcia, L.M.; Aguiar, J.M.; Carro, B. Temperature and Relative Humidity Estimation and Prediction in the Tobacco Drying Process Using Artificial Neural Networks. Sensors 2012, 12, 14004. [CrossRef]

67. Olvera-Gonzalez, E.; Rivera, M.M.; Escalante-Garcia, N.; Flores-Gallegos, E. Modeling energy led light consumption based on an artificial intelligent method applied to closed plant production system. Appl. Sci. 2021, 11, 2735. [CrossRef]

68. Wang, H.; Sanchez-Molina, J.A.; Li, M.; Díaz, F.R. Improving the performance of vegetable leaf wetness duration models in greenhouses using decision tree learning. Water 2019, 11, 158. [CrossRef]

69. Patil, S.L.; Tantau, H.J.; Salokhe, V.M. Modelling of tropical greenhouse temperature by auto regressive and neural network models. Biosyst. Eng. 2008, 99, 423-431. [CrossRef]

70. Dariouchy, A.; Aassif, E.; Lekouch, K.; Bouirden, L.; Maze, G. Prediction of the intern parameters tomato greenhouse in a semi-arid area using a time-series model of artificial neural networks. Meas. J. Int. Meas. Confed. 2009, 42, 456-463. [CrossRef]

71. He, F.; Ma, C. Modeling greenhouse air humidity by means of artificial neural network and principal component analysis. Comput. Electron. Agric. 2010, 71, S19-S23. [CrossRef]

72. Castañeda-Miranda, A.; Castaño, V.M. Smart frost control in greenhouses by neural networks models. Comput. Electron. Agric. 2017, 137, 102-114. [CrossRef]

73. Codeluppi, G.; Davoli, L.; Ferrari, G. Forecasting air temperature on edge devices with embedded Ai. Sensors 2021, $21,3973$. [CrossRef] [PubMed]

74. Sumalan, R.L.; Stroia, N.; Moga, D.; Muresan, V.; Lodin, A.; Vintila, T.; Popesc, C.A. A Cost-effective embedded platform for greenhouse environment control and remote monitoring. Agronomy 2020, 10, 936. [CrossRef]

75. Mahmood, F.; Govindan, R.; Bermak, A.; Yang, D.; Khadra, C.; Al-Ansari, T. Energy utilization assessment of a semi-closed greenhouse using data-driven model predictive control. J. Clean. Prod. 2021, 324, 129172. [CrossRef]

76. Jung, D.-H.; Kim, H.-J.; Kim, J.Y.; Lee, T.S.; Park, S.H. Model predictive control via output feedback neural network for improved multi-window greenhouse ventilation control. Sensors 2020, 20, 1756. [CrossRef]

77. Iddio, E.; Wang, L.; Thomas, Y.; McMorrow, G.; Denzer, A. Energy efficient operation and modeling for greenhouses: A literature review. Renew. Sustain. Energy Rev. 2020, 117, 109480. [CrossRef]

78. Rodrigues, E.; Gomes, Á.; Gaspar, A.R.; Henggeler Antunes, C. Estimation of renewable energy and built environment-related variables using neural networks-A review. Renew. Sustain. Energy Rev. 2018, 94, 959-988. [CrossRef]

79. Zheng, M.; Leib, B.; Wright, W.; Ayers, P. Neural models to predict temperature and natural ventilation in a high tunnel. Trans. ASABE 2019, 62, 761-769. [CrossRef]

80. Yu, H.; Chen, Y.; Hassan, S.G.; Li, D. Prediction of the temperature in a Chinese solar greenhouse based on LSSVM optimized by improved PSO. Comput. Electron. Agric. 2016, 122, 94-102. [CrossRef]

81. Reynolds, J.; Ahmad, M.W.; Rezgui, Y.; Hippolyte, J.L. Operational supply and demand optimisation of a multi-vector district energy system using artificial neural networks and a genetic algorithm. Appl. Energy 2019, 235, 699-713. [CrossRef]

82. Manda, A.; Walker, R.B.; Khamanga, S.M.M. An artificial neural network approach to predict the effects of formulation and process variables on prednisone release from a multipartite system. Pharmaceutics 2019, 11, 109. [CrossRef]

83. Siderska, J. Neural Model for Assessing the Value of Social Capital. Procedia Eng. 2017, 182, 643-650. [CrossRef]

84. Świetlicka, I.; Kuniszyk-Jóźkowiak, W.; Świetlicki, M. Artificial neural networks combined with the principal component analysis for non-fluent speech recognition. Sensors 2022, 22, 321. [CrossRef]

85. Allouhi, A.; Choab, N.; Hamrani, A.; Saadeddine, S. Machine learning algorithms to assess the thermal behavior of a Moroccan agriculture greenhouse. Clean. Eng. Technol. 2021, 5, 100346. [CrossRef] 